\title{
A Comprehensive Review on the Synthesis, Characterization, and Biomedical Application of Platinum Nanoparticles
}

\author{
Muniyandi Jeyaraj ${ }^{\dagger}$, Sangiliyandi Gurunathan ${ }^{+} \oplus$, Muhammad Qasim $₫$, Min-Hee Kang $₫$ and \\ Jin-Hoi Kim *(1) \\ Department of Stem Cell and Regenerative Biotechnology and Humanized Pig Center (SRC), Konkuk Institute \\ of Technology, Konkuk University, Seoul 05029, Korea; muniyandij@yahoo.com (M.J.); \\ gsangiliyandi@yahoo.com (S.G.); qasimattock@gmail.com (M.Q.); pocachippo@gmail.com (M.-H.K.) \\ * Correspondence: jhkim541@konkuk.ac.kr; Tel.: +82-2-450-3687 \\ + Those authors contributed equally to this work.
}

Received: 6 November 2019; Accepted: 25 November 2019; Published: 2 December 2019

\begin{abstract}
Platinum nanoparticles (PtNPs) are noteworthy scientific tools that are being explored in various biotechnological, nanomedicinal, and pharmacological fields. They are unique because of their large surface area and their numerous catalytic applications such as their use in automotive catalytic converters and as petrochemical cracking catalysts. PtNPs have been widely utilized not only in the industry, but also in medicine and diagnostics. PtNPs are extensively studied because of their antimicrobial, antioxidant, and anticancer properties. So far, only one review has been dedicated to the application of PtNPs to nanomedicine. However, no studies describe the synthesis, characterization, and biomedical application of PtNPs. Therefore, the aim of this review is to provide a comprehensive assessment of the current knowledge regarding the synthesis, including physical, chemical, and biological and toxicological effects of PtNPs on human health, in terms of both in vivo and in vitro experimental analysis. Special attention has been focused on the biological synthesis of PtNPs using various templates as reducing and stabilizing agents. Finally, we discuss the biomedical and other applications of PtNPs.
\end{abstract}

Keywords: synthesis; characterization; biomedical applications; cytotoxicity; anticancer; combination therapy

\section{Introduction}

Nanotechnology is a burgeoning field and is widely applied to biomedical engineering and nanomedicine. Numerous technologies are involved in the fabrication of nanomaterials from various sources such as physical, chemical, and biological materials, and different strategies are used to maximize the production of nanomaterials such as the use of different raw materials, temperature, and $\mathrm{pH}$. The global market has a high demand for nanoparticles (NPs), and it is expected that this demand will reach 98 billion dollars by 2025 (Figure 1).

NPs are complex molecules composed of triple-layered surfaces: the surface layer, the shell, and the core [1]. Among other metallic NPs, noble nanomaterials have been used extensively for the applications in fuel cells, organic catalysis, water gas shift reactions, selective oxidation of CO, pharmaceuticals, photonics, electronics, optics, biosensors, biomedical and petrochemical industries, and automobiles [2-4]. Several approaches are used for synthesizing NPs, such as physical, chemical, and biological methods. Conventional methods of NP production involve two approaches: top-down and bottom-up methods [5]. Generally, physical methods consume enormous energy and dissipate 
radiation, whereas chemical methods use several toxic chemicals, which are harmful and hazardous to living beings, and release harmful chemicals into the atmosphere. Consequently, recently, researchers have investigated cleaner, greener, scalable, cost effective, and environmentally benign approaches that can avoid toxic chemicals. Environmentally benign conditions require various templates, including microorganisms, algae, fungi, and plants, and small molecules that can act as alternatives for physical and chemical methods. The morphology and size of the NPs can be controlled by methods such as using different concentrations of reducing agent/capping agent, concentrations of precursors, $\mathrm{pH}$, and temperature. Catalytic nanomaterials like platinum, palladium, and cerium display inimitable physicochemical properties and high surface area and have immense potential for application in various fields. platinum NPs (PtNPs) have led to a new revolution in the field of nanotechnology including the chemical industry, automotive sector, and biomedical applications, and therapeutic span. They are also used in numerous biomedical fields including diagnostics with different agents for imaging, medical implants, drug delivery, and photothermal therapy [6-8].

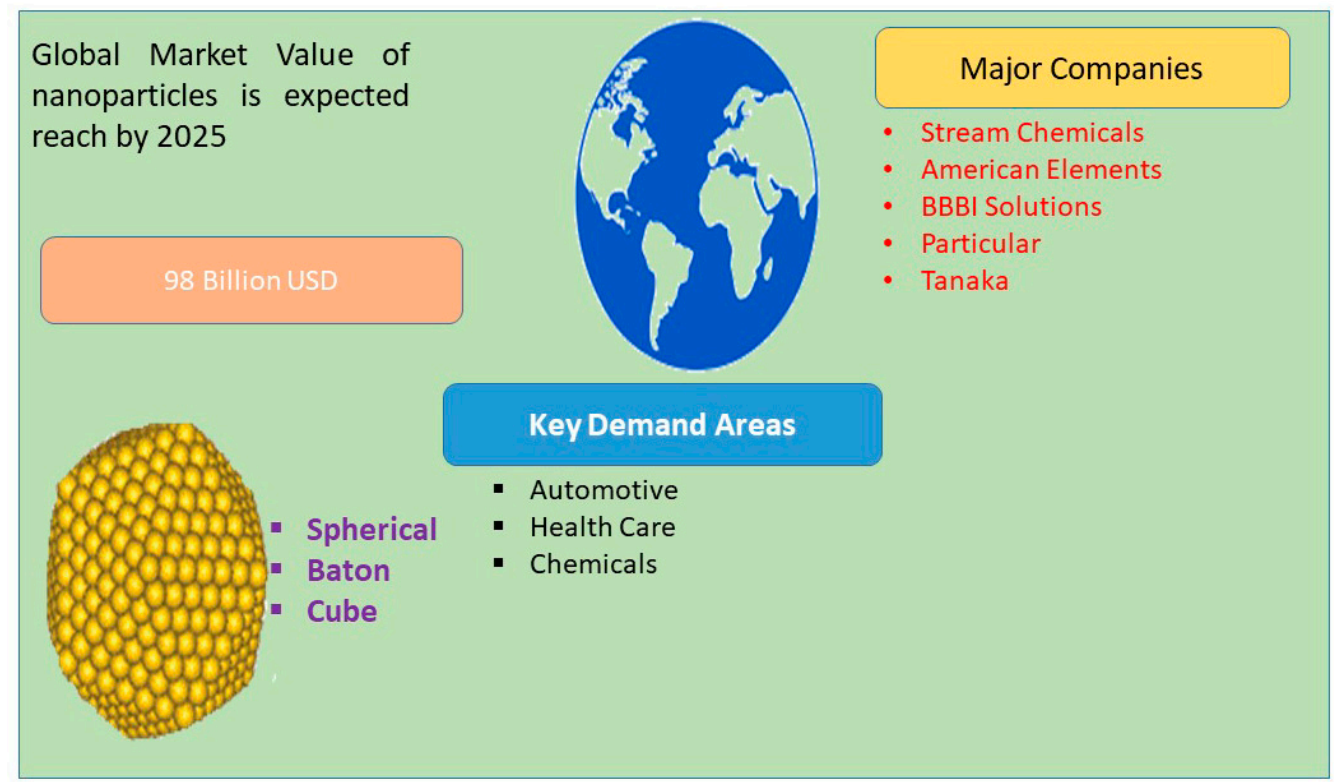

Figure 1. Global market value of nanoparticles in 2025.

PtNPs and their alloys exhibit excellent catalytic properties because of their large surface areas. They are mainly used to reduce pollutants and play a major role in the chemical reactions for synthesis of various chemicals in the chemical industry such as oxidation in the process of organic acid production [9]; dehydrogenation [10-13]; and hydrogenation reactions for synthesis of biofuel [14], vitamins, and fats [15]. They are also used in green technologies, such as highly polluting aromatic compound [16], solar energy harvesting [17], and water treatment [18,19], and to maintain a clean environmental. Currently, both the research and industrial fields have shown considerable interest in the synthesis of catalytic PtNPs for use in therapeutic applications because of their low toxicity, high stability, and less side effects. Although several reports have studied PtNPs, a comprehensive review about synthesis, characterization, and biomedical applications remains elusive and unexplored [20-23]. Here, we focus on the synthesis, characterization, and properties of PtNPs and discuss the mechanisms of cytotoxicity and therapeutic applications of PtNPs in cancer cells.

\section{Classification of Nanomaterials}

NPs are commonly classified based on their morphology, dimensions, shape, composition, uniformity, and agglomeration. Recently, three morphologies of NPs were identified: spherical, crystalline, and flat (Figure 2). NPs are also classified into four types based on electron movement of dimension: 0 dimension; 1D, which includes thin films that are mainly used in electronic devices 
and sensor mechanisms; 2D, which includes second-generation NPs such as carbon nanotubes, which provide high absorption and stability; and 3D, which includes dendrimers and quantum dots [24,25]. These are further classified based on their chemical structures into inorganic, organic, and carbon-based NPs (fullerenes).



Figure 2. Conventional methods of synthesis of nanoparticles.

\subsection{Inorganic Nanoparticles}

Inorganic NPs are fabricated from materials without carbon and are further classified into two major categories: metals and metal oxide NPs. NPs are synthesized from metals such as platinum $(\mathrm{Pt})$, silver $(\mathrm{Ag})$, gold $(\mathrm{Au})$, cadmium $(\mathrm{Cd})$, cobalt $(\mathrm{Co})$, iron $(\mathrm{Fe})$, copper $(\mathrm{Cu})$, and zinc $(\mathrm{Zn})$. These NPs have distinctive sizes, shapes, surface areas, and densities.

\subsection{Metal Oxide Nanoparticles}

Metal oxide NP is mainly synthesized for increase their efficiency, reactivity and modify the properties. Aluminum oxide $\left(\mathrm{Al}_{2} \mathrm{O}_{3}\right)$, cerium oxide $\left(\mathrm{CeO}_{2}\right)$, iron oxide $\left(\mathrm{Fe}_{2} \mathrm{O}_{3}\right)$, zinc oxide $(\mathrm{ZnO})$, silicon dioxide $\left(\mathrm{SiO}_{2}\right)$, and titanium oxide $\left(\mathrm{TiO}_{2}\right)$ are usually used for synthesis of NPs.

\subsection{Organic Nanoparticles}

Organic NPs are made up of organic polymers such as dendrimers, liposomes, ferritin, and micelles. Micelles and liposomes are sensitive to electromagnetic radiation and the thermal effect [26]. They are mainly used for targeted drug delivery because of their efficient drug delivery capabilities and nontoxicity.

\subsection{Carbon-based Nanoparticle}

Carbon-based NPs are fabricated from carbon and are widely used in biomedical applications. They include fullerenes, graphene, carbon nanotubes, carbon nanofibers, and carbon black. 


\section{Methods for Synthesis of PtNPs}

Several methods exist for the fabrication of NPs, which can be largely divided into two major categories: bottom-up and top-down approaches (Figure 3).

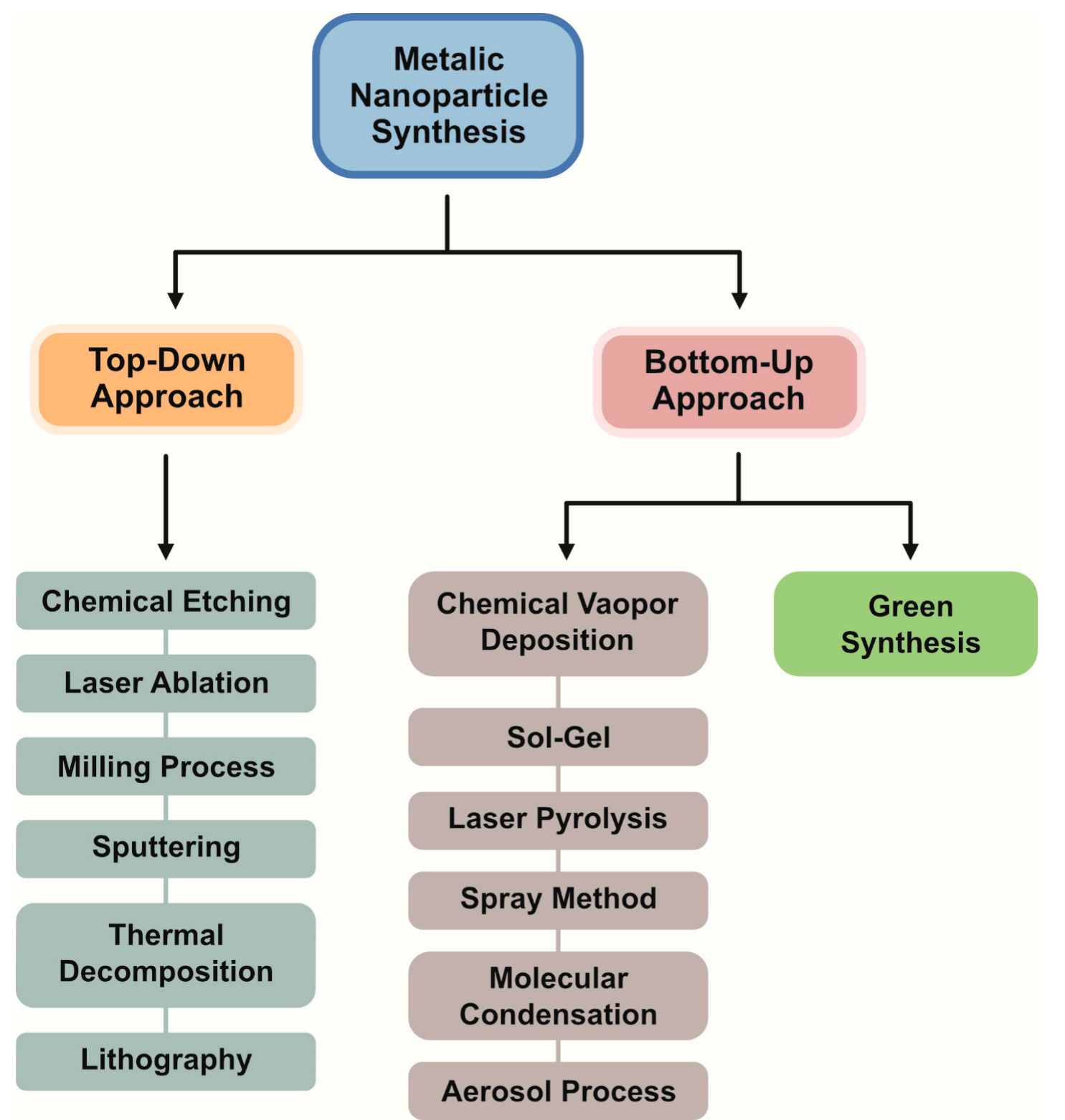

Figure 3. Schematic representation illustrating the various approaches used for synthesis of platinum nanoparticles.

\subsection{Bottom-Up Approaches}

To produce PtNPs with controlled sizes and desirable characteristics for various applications, two basic approaches are adopted $[27,28]$ :

(1) Top-down approaches

In the top-down approach, a larger metal is used for the production of NPs by a physical method via the mechanical breakdown of the large metal structure. It is an economic, energy demanding, and lengthy process. Its major advantage is the control of the size distribution and morphologies of NPs [29]. The top-down approach begins with the bulk counterpart that leaches out systematically 
bit-after-bit, leading to the generation of fine NPs. Several physical methods are adopted for the mass production of NPs such as photolithography, electron beam lithography, milling techniques, anodization, and ion and plasma etching [30].

\section{(2) Bottom-up approaches}

The bottom-up approach involves assembling atoms and molecules to generate a diverse range of NPs. Examples of the bottom-up approach include self-assembly of monomer/polymer molecules, chemical or electrochemical nanostructural precipitation, sol-gel processing, laser pyrolysis, chemical vapor deposition (CVD), plasma or flame spraying synthesis, and bio-assisted synthesis [31]. In general, NP synthesis methods can be divided into three groups-(1) physical methods, (2) chemical methods, and (3) biological methods, also known as constructive methods (Figure 4).

\subsection{Physical Methods}

Synthesis of PtNPs involves the application of mechanical pressure, high energy radiation, thermal energy, or electrical energy to cause material abrasion, melting, evaporation, or condensation to generate NPs. The physical methods of synthesis of PtNPs include evaporation and condensation using a tube furnace at atmospheric pressure. The merits of physical methods are high speed and no use of toxic chemicals, purity, uniform size, and shape, whereas their demerits include less productivity; high cost; exposure to radiation; require high energy, temperature, and pressure; less thermal stability; high amount of waste, high dilution; difficult size and shape tunability; and less possibility in stability. This method is not suitable for preparing familiar shapes and sizes of nanoparticles; it also changes in surface and physicochemical chemistry of nanoparticles. Several physical methods are available, such as laser ablation, arc discharge, vapor deposition, melt mixing, ball milling, sputter deposition, and flame pyrolysis [30]. Laser ablation is a very simple but expensive method and involves the removal of materials from a solid rarely liquids surface by irradiating it with a laser beam. Here, a laser beam is used instead of electric heating. Although the energy efficiency of laser ablation is good, its energy production cost is high. The absorbed laser energy is used by low laser flux materials, thus converting the material to plasma. The major application is weak of agglomeration and lack impurities, previously several researchers reported that preparation of PtNPs by pulsed laser ablation in liquid (PLAL) [31-34]. Milling process involves reducing the size of particles and blending the particles into new phases. Materials can be selectively removed from the substrate in a suitable medium in the presence of reducing agents. $\mathrm{C}_{6} \mathrm{H}_{5} \mathrm{O}_{7} \mathrm{Na}_{3}, \mathrm{~N}_{2} \mathrm{H}_{4}$, and $\mathrm{NaBH}_{4}$ are frequently used for chemical reduction processes. Solvothermal processes increase the solubility of the reactants and enable the reaction to take place at a low temperature. It is a low-temperature method that uses polar solvents, which are used under pressure and at above their boiling points. Inert gas condensation (IGC) methods involve evaporation of metals by vacuum chambers filled with inert gas at a typical pressure of $100 \mathrm{~Pa}$. IGC is a highly efficient method for the synthesis of good quality silver and PtNPs [35]. In this method, inter atomic collision occurs between gas atoms within a chamber, and the evaporated metal atoms lose their kinetic energy to condense in the form of a crystal which accumulates in liquid nitrogen. This method is mainly used for synthesis of gold NPs. 




Figure 4. Synthesis of platinum nanoparticles using conventional methods and their applications.

\subsection{Chemical Methods}

Chemical synthesis of NPs follows the bottom-up approach. This process mainly involves the use of water-soluble cations as a precursor to trigger their reduction to metal monomers, and the process is called nucleation. The growth of particles where it assembled cluster of reduced metal atom automatically stop the growth controlled by reducing agent/capping. The particles reached a certain size which is stable thermally. Nanomaterials are synthesized by the interaction of atoms and smaller molecules. Various chemical synthesis techniques include the sol-gel process, pyrolysis, CVD, microemulsion, hydrothermal, polyol synthesis, and plasma-enhanced chemical vapor deposition. Chemical preparation involves synthesis of metal NPs in a chemical solution, and various chemical reactions and chemical compositions are used for these purposes. For instance, the chemical reduction of metal ions inside reversed micelles in a nonpolar solvent is the most commonly employed method for the preparation of metal nanoparticles (MNPs) [36]. For instance, first, a metal slat dissolved in water is confined in the reversed micelles and is reduced into MNPs by chemical reduction. Size control of the particles is important and is regulated by volume of reversed micelles and ratio of water. Several points need to be considered for synthesis of PtNPs such as the appropriate shape and size and the appropriate selection of solvent, temperature, and reducing/capping agent. The method should also avoid aggregation. The advantage of chemical methods is cost effective, high versatility in surface 
chemistry, easy functionalization, high yield, size controlled, thermally stable, and reduced dispersity. Disadvantages of chemical methods include low purity and the use of toxic chemicals and organic solvents, which can be hazardous to human beings and the environment.

Chemical methods are important, established methods of NP synthesis. In the early 1920s, Adam et al. [37] prepared bulk type $\mathrm{PtO}_{2}$ using a fusion method at $450{ }^{\circ} \mathrm{C}$. Next, numerous methods were used to modify the material into NPs. NP production is efficient and low cost but requires toxic chemicals. Several studies have reported chemical synthesis of PtNPs [38-44]. There are three imperative components employed for the synthesis-metal precursors, capping/stabilizing agent, and reducing agent. In general, PtNPs can be synthesized by two methods-the top-down and bottom-up processes. Numerous chemical methods have been used for synthesis of NPs such as wet chemical reduction [45], microemulsion [46], electrochemical process [47,48], confined reaction, photochemical reduction [49,50], hydrolysis [51], thermal decomposition [52], sono-decomposition [53,54], chemical vapor deposition [55,56], and coprecipitation. Wet chemical reduction is often used in laboratory research to control particle sizes. Chemical reduction is mainly used for colloidal metal NP production, in which chemical agents reduce the metallic ion, thus forming metallic NPs (Figure 5). Reducing agents like sodium borohydride $(\mathrm{NaBH} 4)$, potassium bitartrate $\left(\mathrm{KC}_{4} \mathrm{H}_{5} \mathrm{O}_{6}\right)$, methoxy polyethylene glycol $\left(\mathrm{CH}_{3} \mathrm{O}\left(\mathrm{CH}_{2} \mathrm{CH}_{2} \mathrm{O}\right) \mathrm{nH}\right)$, trisodium citrate dihydrate $\left(\mathrm{Na}_{3} \mathrm{C}_{6} \mathrm{H}_{9} \mathrm{O}_{9}\right)$, ascorbate, and elemental hydrogen are used for the reduction process. The size and shape of the synthesized NPs varies depending on reaction temperature [57], reducing agent [58-61], and concentration of the platinum compound (Figure 6).



Figure 5. Chemical reduction for platinum nanoparticle synthesis. 




Figure 6. Chemical synthesis of doped platinum nanoparticles.

\subsection{Biological Synthesis of PtNPs}

Biological synthesis or biomolecule-assisted synthesis is commonly used for the production/ fabrication of PtNPs. The advantage of biological methods is that they are simple, facile, and environmentally friendly, and the synthesized nanomaterials are nontoxic and biocompatible. NPs with definite size and shape can be produced by adjusting the concentration of reducing agent, temperature, and $\mathrm{pH}$ [62]. The synthesis of PtNPs using biological systems is limited compared with the synthesis of silver, gold, and other metal NPs. Therefore, we critically assess the role of biological systems in the synthesis of PtNPs. A few plant species are used for the synthesis of PtNPs including Azadirachta indica, Diospyros kaki, Ocimum sanctum, and Pinus resinosa. Several studies have reported the biological synthesis of PtNPs using different microorganisms. For the synthesis of PtNPs, water soluble metal salts are frequently used, such as $\mathrm{H}_{2} \mathrm{PtCl}_{6}, \mathrm{~K}_{2} \mathrm{PtCl}_{6}, \mathrm{~K}_{2} \mathrm{PtCl}_{4}, \mathrm{PtCl}_{2}, \mathrm{Pt}(\mathrm{AcAc})_{2}, \mathrm{Pt}\left(\mathrm{NH}_{3}\right)_{4}-(\mathrm{OH})_{2}$, $\mathrm{Pt}\left(\mathrm{NH}_{3}\right)_{4}\left(\mathrm{NO}_{3}\right)_{2}$, and $\mathrm{Pt}\left(\mathrm{NH}_{3}\right)_{4} \mathrm{Cl}_{2}$ (Figure 7). The potential benefit of biological method of synthesis was that the produced nanoparticles were soluble, biocompatible, sustainable, chemical free, cost effective, and eco-friendly. The disadvantage of this method is hard to control shape, size, crystal growth, stability and aggregation, and possible endotoxin and time-consuming purification processes.
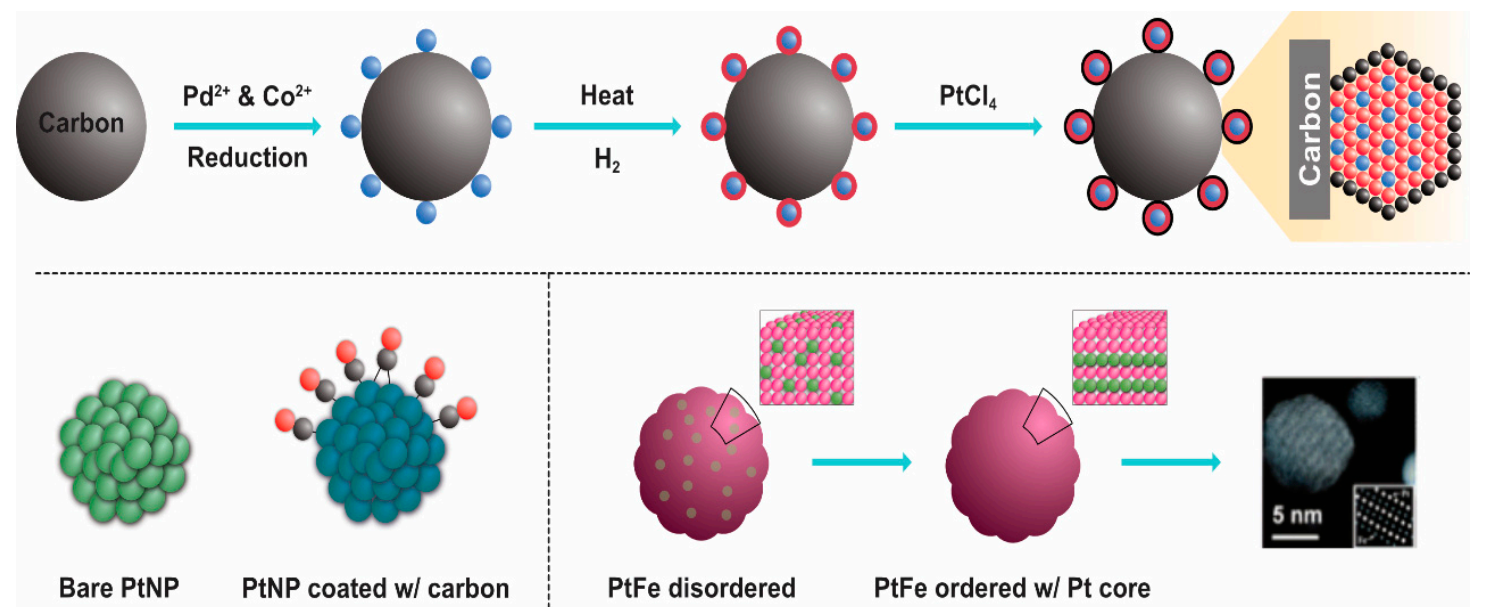

Figure 7. Synthesis of platinum nanoparticles using various types of metal salts.

Several methods have used for the synthesis of NPs from various sources and diverse methods. Each method has certain limitations and advantages. Stable NPs are prepared from chemical methods, but they are unconducive for biomedical applications, especially for drug delivery systems. Chemical methods lead to concerns regarding biosafety, drug activity, and clinical application. Therefore, it is imperative to develop suitable methods for the synthesis of NPs from biological systems, which are facile and versatile. The fabrication of PtNPs with morphological characteristics, such as nanotubes, cubic NPs, and nanoclusters, is possible and has attained considerable interest for application in catalysis [63-65]. Therefore, clean, nontoxic, environmentally friendly, and green chemistry approach-based synthesis of 
NPs is in great demand. Currently, researchers are exploring biological systems including bacteria-, fungi-, plant-, and small biomolecule-based synthesis of NP. Biological systems are considered the potentially environment friendly nanofactories. These methods have been suggested as alternatives to physical and chemical methods, and the use of alternative methods offers numerous advantages such as no toxicity, cost effectiveness, rapid synthesis, robotic, environmentally benign, monodisperse, and large-scale production, reducing waste production and decreasing production cost [66]. Such methods also have immense potential for application because the sizes of particles produced are very small.

\subsection{Synthesis of Platinum Nanoparticle Using Bacteria}

Single cellular and multicellular organisms are known to produce inorganic material either extracellularly or intracellularly [67]. Generally, bacteria produce NPs by the reduction process. The conversion of metal ion to NP using intracellular signaling pathways involves bacterial enzymes (Figure 8). The major advantages of bacteria-based NP synthesis is the ease of handling. The synthesis can also be easily modified using genetic engineering techniques for specific purposes, to reduce toxicity, and to obtain sustainable NP production. This method also has some disadvantages like laborious method, high cost, downstream processing, and less control over their size and shape. For instance, metal NPs like silver were synthesized using both intra- and extracellular bacterial extracts $[68,69]$. This process consumes a lot of time for downstream processing for the purification of AgNPs from cellular extracts. Riddin et al. [70] reported the successful synthesis of geometric PtNPs using cell-free, cell-soluble protein extracts from a consortium of sulfate-reducing bacteria compared to whole cells from the same culture, which produce amorphous $\mathrm{Pt}^{(0)}$. Synthesis of PtNPs was carried out by sulfate reducing bacteria Desulfovibrio desulfuricans [71] and Acinetobacter calcoaceticus [72]. These bacteria can potentially reduce platinum (IV) ion into platinum ${ }^{(0)} \mathrm{NPs}$ within $24 \mathrm{~h}$, and the maximum production was observed at $\mathrm{pH} 7.0$ under $30^{\circ} \mathrm{C}$. The NPs are $2-3.5 \mathrm{~nm}$ in size with a cuboidal structure. PtNPs are deposited by metal-ion reducing bacterium Shewanella algae, and the resting cells of PtNPs by reducing ion $\mathrm{PtCl}_{6}{ }^{2-}$ into elemental platinum at neutral $\mathrm{pH}$ and room temperature. NPs $5 \mathrm{~nm}$ in size have been reported to be located in the periplasmic space of $S$. algae. The biological process involves two main processes-uptake and deposition or assimilation [73].

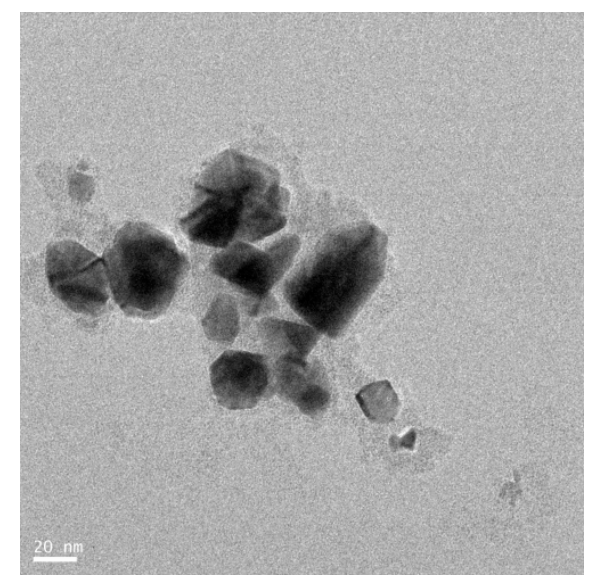

Figure 8. Transmission electron microscopy image of platinum nanoparticles produced by Bacillus spp.

\subsection{Synthesis of Platinum Nanoparticles Using Fungi}

Numerous fungal species have been used for synthesis of NP. The use of fungi, as compared to prokaryotes or plants, is more advantageous because monodispersed NPs with well-defined dimensions are produced, fungi require simple media for growth, scale-up production and downstream processing are easy, the biomass is easy to handle, high amounts of proteins are secreted [74-76], enzyme production enhances the reductive properties and also increases the amount of NP produced [77], very stable NPs are produced, and molecular aggregation can be prevented $[78,79]$. Thus, researchers have 
explored the use is fungus as an excellent candidate for the fabrication of nanomaterials. Most fungi produce metal NPs either by intracellular or extracellular processes. Extracellularly produced NPs have good commercial feasibility and are nontoxic. Syed and Ahmad [76] reported that the synthesis of PtNPs using Fusarium oxysporum, which produces PtNPs extracellularly at room temperature. The morphology and size of the NPs was found to be spherical and 15-30 nm, respectively, as determined by TEM analysis (Figure 9). Castro-Longoria et al. [80] reported the use of Neurospora crassa fungus for the synthesis of PtNPs. They produced NPs intracellularly at an ambient temperature. The produced particles were found to be quasi-spherical and single crystalline nanoaggregates with an average size between 20 and $110 \mathrm{~nm}$. Altogether, these studies confirmed that fungal extracts can be used as a reducing and stabilizing agent for synthesis of PtNPs.

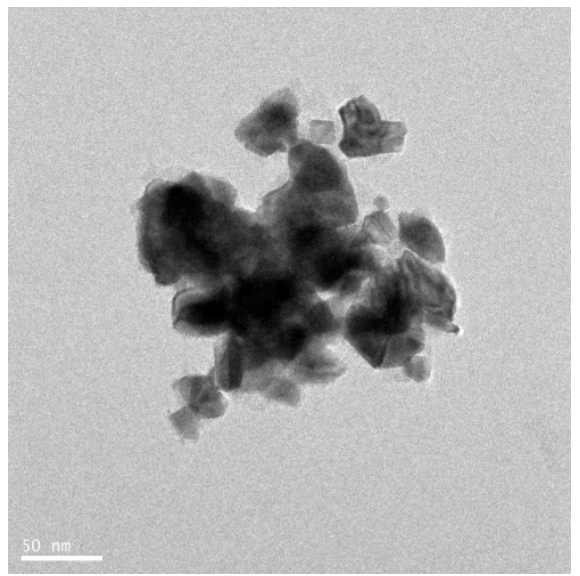

Figure 9. HR-TEM micrograph of platinum nanoparticles produced by fungi (Ganoderma spp.).

\subsection{Green Synthesis of Platinum Nanoparticles Using Plants}

Common biological methods for synthesis of NPs include several organisms such as bacteria, actinomycetes, algae, and fungi. Although microorganisms are exploited for the synthesis of PtNPs, controversy still exists regarding the use of microorganisms because the production time of NPs is high because of the time required to grow bacterial/fungus cultures and for bacterial cell maintenance. Therefore, researchers are interested in exploiting the use of plants and plant extracts, which are readily available and abundant and do not require any media to grow. Plant-based synthesis of NPs has numerous advantages over the other types of biological methods (Figure 10). Gardea-Torresday et al. [81] first synthesized NPs in living plants and fabricated gold NPs from Alfalfa seedlings with size ranging from 2 to $20 \mathrm{~nm}$. Biological templates used for the synthesis of PtNP are shown in Table A1.



Figure 10. Platinum nanoparticles synthesized by plant extract/phytochemical method. 
The extracellular synthesis of PtNPs in the plant system was first described by Song et al. [82]. The Diospyros kaki leaf extract was used for the synthesis of NPs. At $95^{\circ} \mathrm{C}$, color changes were observed due to the excitation of surface plasmon vibration in the metal NPs, which was analyzed by UV-Vis spectroscopy; the conversion of platinum was observed at $477 \mathrm{~nm}$. The TEM studies indicated the formation of NPs with an average size of 2-12 $\mathrm{nm}$. The leaf extract was used as a reducing agent, and it was an extracellular and non-enzyme-mediated process. They used low biomass concentration, and high yield was achieved. Production of pentagonal and hexagonal shapes of the PtNPs was accomplished using an extract of Fumariae herba [83]. The synthesis was carried out at $50{ }^{\circ} \mathrm{C}$ for $4 \mathrm{~h}$. Color changes were observed from yellow to brown and UV-Vis spectrometer analysis showed the peak. Both results confirmed the formation and complete reduction of $\mathrm{Pt}^{4}$ ions to $\mathrm{Pt}^{(0)} \mathrm{NPs}$. The average size of NPs was 10-30 nm. The catalytic activity was analyzed by studying the reduction of two different dyes-methylene blue and crystal violet. Sheny et al. [84] reported the synthesis of PtNPs from Anacardium occidentale leaf extract. Different $\mathrm{pH}$ values were used for the synthesis of NPs. Qualitative analysis of color, which is a characteristic of PtNP formation, and UV analysis revealed the reduction of platinum ions to PtNPs; the $\mathrm{pH}$ range of 6 to 9 was suitable for the formation of NPs. TEM micrographs showed the formation of crystalline NPs of irregular rod shapes. NPs have good potential for the reduction of aromatic nitrocompounds because secondary metabolites are present in the leaf. NanosolutionS-containing small amounts of PtNPs are found to have high thermal conductivity than those without NP solutions. Therefore, the thermal conductivity of platinum colloid shows comparative to increase with volume of fraction. PtNPs were also synthesized neem leaf extracts [85]. The color changes from yellow to brown and UV-Vis spectrum analysis suggested the formation of PtNPs and the reduction of ions to platinum. The TEM images showed the formation of polydispersed small-to-large spherical NPs with a size ranging between 5 and $50 \mathrm{~nm}$. FTIR spectra showed sharp peaks corresponding to carbonyl, alkynes, and aliphatic amines. The extract contained terpenoids which act as a reducing and stabilizing agent. Piper beetle leaf extract has been used to synthesize PtNPs [86]. The TEM images show a cubic (fcc) structure and monocrystalline nature. The average size of the NPs was $2 \mathrm{~nm}$. The fcc structure of NPs clearly indicates that the NPs were composed of highly crystalline PtNPs. Dioscorea bulbifera tuber extract has been used for the synthesis of PtNPs. The reaction conditions were $95^{\circ} \mathrm{C}$ for $5 \mathrm{~h}$, and the morphology of the synthesized NPs was found to be spherical and $5 \mathrm{~nm}$ in size, as analyzed by TEM analysis.

A study described the biogenic fabrication of PtNPs using the leaf extract of medicinal plant Ocimum sanctum [87]. The optimal reaction temperature was set at $100{ }^{\circ} \mathrm{C}$, which is higher than that required for normal synthesis processes. A high temperature is favorable for rapid synthesis of NPs. By this process, the authors produced NPs with an average size of $23 \mathrm{~nm}$, and the shapes of the particles were irregular. The leaf extracts are bioactive, containing various antioxidants, phenolic compounds, flavonoids, ascorbic acid, gallic acid, terpenoids, amino acid, and certain proteins that act as reducing agents. Previously, Huang et al. [88] demonstrated that biomolecules derived from plant extracts that are suitable reducing agents are found to have a major role, over their counterparts, as protecting agents. For instance, Ipomea carnea plant extracts produce NPs with an average size of $50 \mathrm{~nm}$ (Figure 11). 


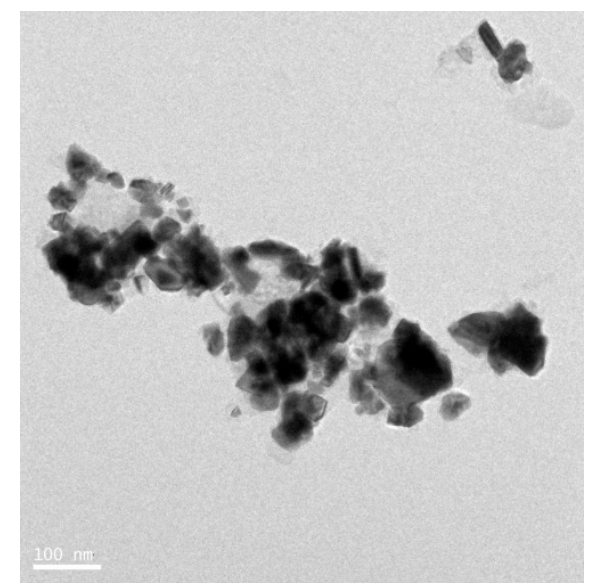

Figure 11. HR-TEM image of platinum nanoparticle produced by plant extracts of Ipomea carnea.

Gloriosa superba roots are mainly used as a germicide and for treatment of leprosy, inflammation, flatulence, intermittent fever, debility, ulcers, piles, hemorrhoids, scrofula, dyspepsia, worm infestation, arthritis, and against snake poison [89]. The fabrication of PtNPs at high temperatures formed spherical particles $0.83 \mathrm{~nm}$ in size. This result agreed with the production of NPs with other medicinal plants like D. bulbifera, Barleria prionitis, and Ocimum. These results were finding to synthesis of PtNPs by using medicinal plants. Similar sizes of PtNPs were produced by Cacumen platycladi at $90{ }^{\circ} \mathrm{C}$, ranging from 0.8 to $2 \mathrm{~nm}$. Coccia et al. [90] reported the one-spot synthesis of PtNPs from natural second biopolymer lignin isolated from red pine (Pinus resinosa) and fulvic acid.

The reaction was carried out at optimum $\mathrm{pH}(7.0)$ and at $80{ }^{\circ} \mathrm{C}$. The formation of NPs with lignin was confirmed by color changes from orange to dark brown, as analyzed by the subsequent UV spectra analysis at $257 \mathrm{~nm}$ after $4 \mathrm{~h}$. Peaks were also obtained for fulvic acid at $280 \mathrm{~nm}$ in the presence of phenolic groups. NMR spectral analysis showed two signals $\left(\mathrm{PtCl}_{6}{ }^{2-}\right.$ and $\mathrm{PtCl}_{5}(\mathrm{H} 2 \mathrm{O})^{-}$ which gradually disappeared as a result of the formation of NPs. The shape of the platinum particle was predominantly irregular forming clusters and particles ranging in size from 6 to $8 \mathrm{~nm}$. The resultant lignin and fulvic acid were found to act as both reducing and stabilizing agents. Najlaa S. Al-Radadi [91] used date extracts to biologically synthesize PtNPs. The ensuing size of the PtNPs ranged between 1.3 and $6 \mathrm{~nm}$, and the shape of the NPs was homogeneous small spheres. The flavanols worked as reducing and capping agents. Assessment of the resulting PtNP solution demonstrated the antibacterial activity against $E$. coli and B. subtilis, providing promising results against several cell lines. Xiaobo Lin et al. [92] produced spherical and cubic NPs and spherical platinum nanoclusters from natural wood. The synthesized NPs were highly stable, and the catalytic reduction of $p$-nitrophenol was promising as a one-step process. The concentration of the precursors and $\mathrm{pH}$ played a major role in the controlled fabrication of PtNPs. Leaf extracts from invasive weed Lantana (Lantana camara L.) was used for the fabrication of PtNPs. The reaction conditions were $95^{\circ} \mathrm{C}$ for $8 \mathrm{~min}$, and the color was changed to black, indicating the formation of NPs. The UV-Vis spectra revealed the reduction of platinum ions. The TEM images showed that the NPs were spherical in shape and $35 \mathrm{~nm}$ in size [93]. For example, Azadirachta indica is potentially used for synthesis of various nanoparticles silver, gold, palladium, and platinum, and synthesized particles were characterized by various analytical techniques (Figure 12). 

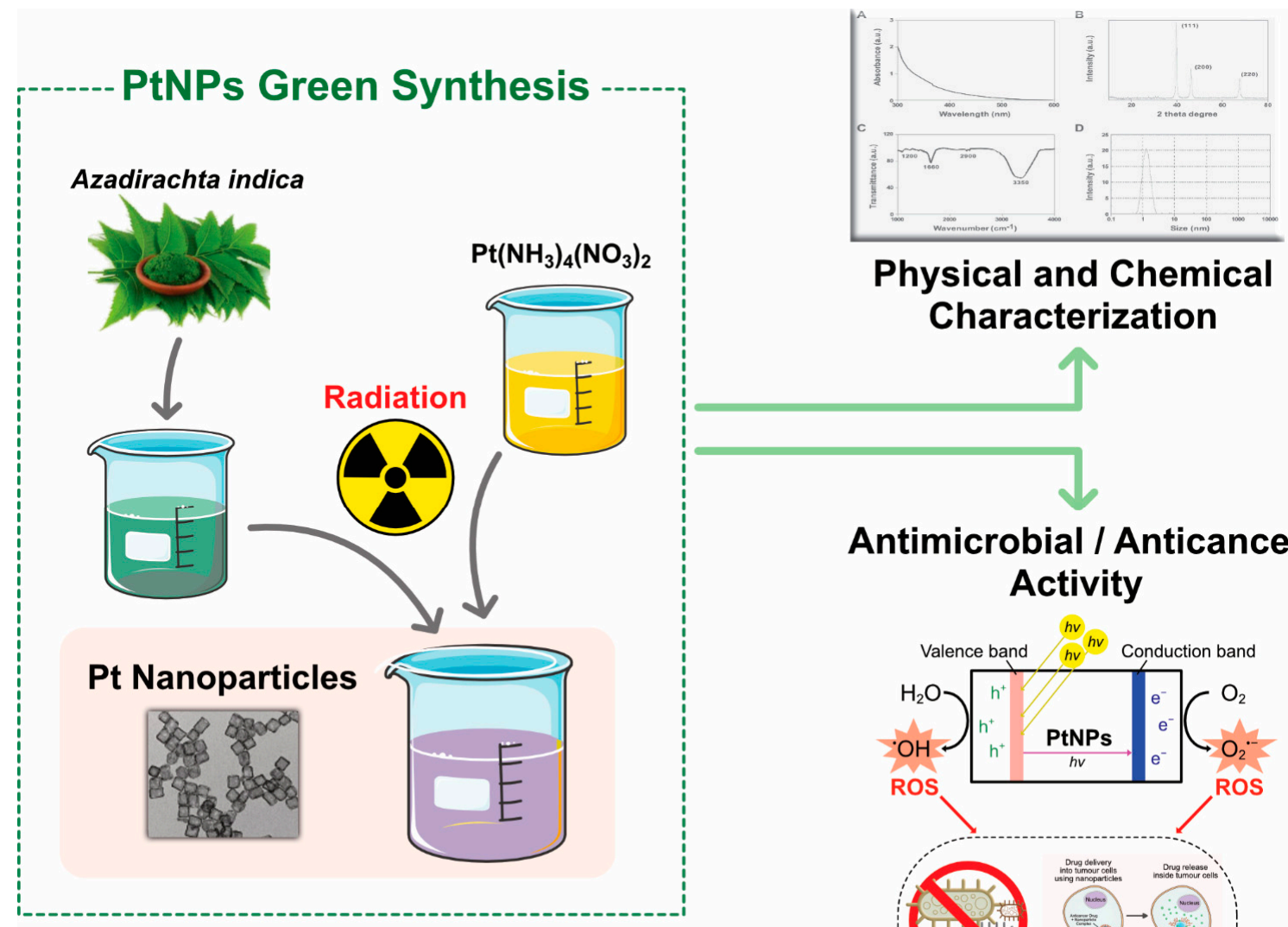

\section{Antimicrobial / Anticancer Activity}

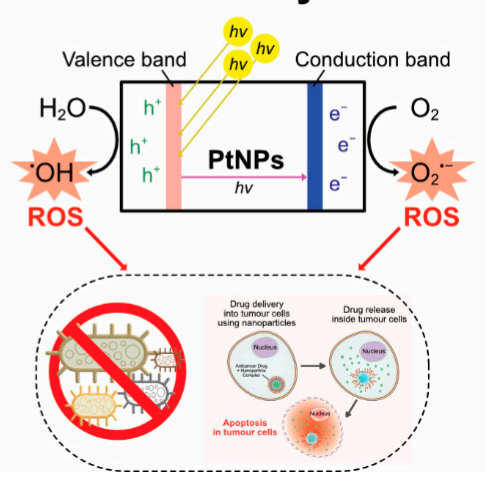

Figure 12. Synthesis, characterization, and application of platinum nanoparticles produced by plant Azadirachta indica.

Prunus yedoensis tree gum extract was found to produce spherical shaped PtNPs with an average particle size of 10-50 $\mathrm{nm}$ [94]. The synthesized NPs were found to be effective against pathogenic fungi. The tea polyphenol from Camellia sinensis was used for fabrication of PtNPs and acted as the reducing and stabilizing agent. PtNPs obtained from tea polyphenol showed a flower-shaped morphology with sizes ranging from 30 to $60 \mathrm{~nm}$. The inhibition of cell proliferation was also evaluated, and it was found to induce apoptosis of cervical cancer cells [95]. Recently, spherical PtNPs of 5-150 nm in size were synthesized from the coral vine Antigonon leptopus. The conversion and formation of PtNPs was confirmed by rapid color changes at an elevated temperature of $95^{\circ} \mathrm{C}$, which represented the formation of PtNPs. The Antigonon leptopus extract acted as a stabilizing and reducing agent for the synthesis of PtNPs [96]. PtNPs have been synthesized using leaf extract from Barleria prionitis. The color change from light brown to dark brown at $100{ }^{\circ} \mathrm{C}$ indicated the formation of PtNP, and the synthesis was confirmed by UV-Vis spectral analysis. Monodispersed NPs of 1-2 nm in size were synthesized using B. prionitis extract, and the FTIR spectra showed several functional group constituents of B. prionitis leaf, which is mainly involved in the reduction and stabilization of NPs. The synthesized PtNPs showed cytotoxic effects against the breast cancer cell line MCF7 [97]. Previously, Preeti Dauthal et al. [98] reported the fabrication of PtNPs from agroindustrial waste of Punica granatum peel extract. TEM images showed that the particles were spherical with sizes ranging between 16 and $23 \mathrm{~nm}$, and X-ray diffraction (XRD) patterns suggested the synthesis of powder form of PtNPs in the plane in predominant orientation. FTIR peaks were observed at $3424 \mathrm{~cm}^{-1}$, which shifted to $3439 \mathrm{~cm}^{-1}$, suggesting that the phenolic group was present in the peel extract, which is involved in the reduction and stabilization of NPs. PtNPs with a spherical shape and an average size of $20.12 \mathrm{~nm}$ were synthesized from pomegranate extract, and the reaction was carried out at room temperature for 
$24 \mathrm{~h}$. The formation of NPs was analyzed by visualization of color changes from yellow to brown, and subsequently, synthesis was confirmed by UV-Vis spectral analysis.

\subsection{Synthesis of Platinum Nanoparticles Using Purified Plant Compounds}

Generally, plant extracts are used for the synthesis of metallic NPs. However, there is no clear understanding regarding the mechanism of synthesis of NPs. Therefore, studies are necessary to understand the synthesis of NPs using individual purified compounds. In addition, to avoid downstream processing, reduce time for production, and increase the scale-up processes, several studies reported the synthesis of various metallic NPs using purified phenolic compounds such as a conjugation of sugars, secondary metabolites, and proteins [99]. TEM images shows the images of purified plant compound synthesized PtNPs exhibited various shapes, such as spherical, cubic, rectangle, triangle, octahedral, and tetrahedral or truncated cubic, hexagonal, octahedral, and tetrahedral, indicating their very sharp corners, edges, and facets (Figure 13). Synthesized NPs revealed potent anticancer activity against a human breast cancer cell line [100]. Similarly, biologically synthesized PtNPs exhibited potential cytotoxicity against various human cells such as human monocytic cells and human bone OS epithelial cells [101,102]. All these data provided strong evidence for the synthesis of PtNPs using natural products and its potential anticancer activity.

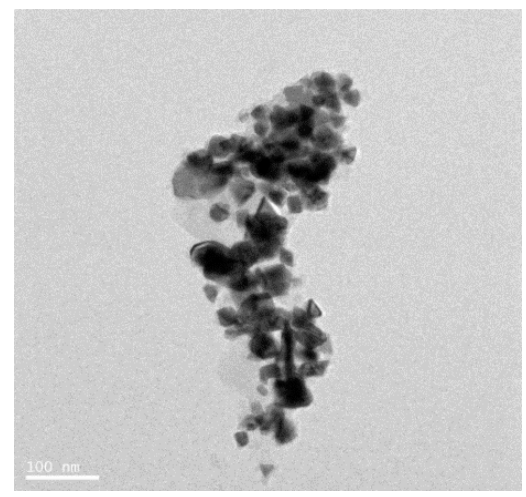

(a)

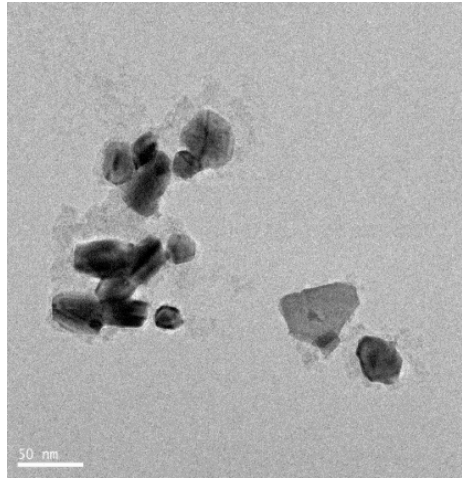

(b)

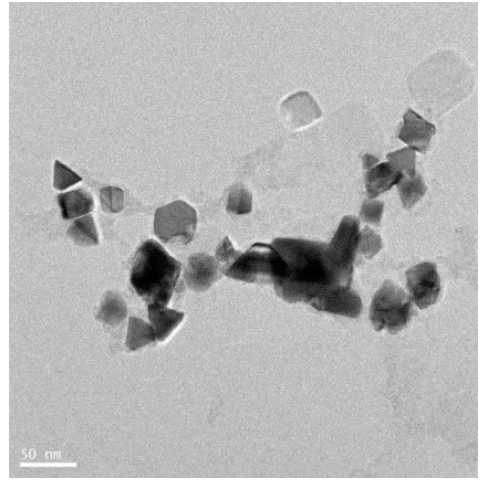

(c)

Figure 13. High-resolution TEM images of platinum nanoparticles and their different shapes and sizes produced by various secondary metabolites of plants. Left panel (a): Platinum nanoparticle synthesis assisted by terpenes. Middle panel (b): Platinum nanoparticle synthesis assisted by phenolic compounds. Right panel (c): Platinum nanoparticle synthesis assisted by S-containing compounds.

\section{Characterization of PtNPs Using Various Analytical Techniques}

Generally, the synthesized NPs are characterized by various analytical techniques such as UV-Visible spectroscopy, XRD, energy-dispersive spectroscopy (EDS), Fourier transform infrared (FTIR) spectroscopy, nanoscale infrared spectroscopy, dynamic light scattering, scanning electron microscopy, TEM, atomic force microscopy (AFM), and extended X-ray absorption fine structure spectroscopy (EXAFS). Briefly, here, we describe the principle of each instrument and how it is useful for NP detection.

\subsection{UV-Visible Spectroscopy}

UV-Visible spectroscopy is generally used to confirm the synthesis and stability of metal $\mathrm{NPs} /$ colloidal particles. Synthesis is confirmed based on the absorbance of the samples at wavelength from 230 to $800 \mathrm{~nm}$, and NPs ranging from 1 to $100 \mathrm{~nm}$ can be used for analysis. The PtNP electron and valence bands are very close to the each other. The free electrons give rise to the surface plasmon resonance absorption band [103]. UV absorption spectroscopy is not only used for the confirmation of synthesis, but also used for the quantitative determination of particles in colloidal solutions. 
Furthermore, absorption spectra determine the size of the particles and can be used for quantitative and qualitative analysis of particles. Spectroscopy involves the measurement and interpretation of electromagnetic radiation absorbed or emitted when the molecules, atoms, or ions of a sample move from one energy state to another. NP samples are analyzed using the absorption of ultraviolet light (200-400 nm) by the molecule which results in the excitation of the electrons from the ground state to higher energy state. The salient features of UV-Vis spectroscopy are easy handling, sealed optics, double choppers, and the spectral bandwidth, which can be set to $0.2 \mathrm{~nm}$.

\subsection{Fourier Transform Infrared Spectroscopy}

Fourier transform infrared spectroscopy (FTIR) is considered a powerful and simple technique. It has an imperative role in biological systems for measuring the concentration of chemicals, surface chemistry, functional group, and atomic arrangement of the biological NP samples [104]. In NP synthesis, FTIR can analyze whether the biomolecules are involved in synthesis or not. It also shows what biomolecules are present in the sample [105-108]. FTIR measurement depends on the vibration of molecular bonds positioned at various frequencies and the type of bonds. The salient features of FTIR are high sensitivity, high cube corner interferometer, customizable workspaces, and hyperspectral imaging.

\subsection{Nanoscale Infrared Spectroscopy}

Infrared spectroscopy (IR) involves a reproducible instrument which is used to analyze the structure of matter at the molecular scale based on the resonant vibration modes of various molecules [109]. It can unveil the elemental composition and bonding arrangement. The intensity of radiation and frequency of the spectrum are plotted, and a unique spectrograph is used to compare with international standards and identify the molecules. Infrared spectroscopy provides the ability to characterize and identify chemical species. However, it its resolution is restricted in the order of 5-10 $\mu \mathrm{m}$. NanoIR is a probe-based measurement tool used to measure the chemical composition of samples at the nanoscale. It comprises key elements of both infrared spectroscopy and AFM to enable the acquisition of infrared spectra at spatial resolutions of 50-200 nm. The salient features of nanoIR include multifunctional measurements. This instrument provides a complete picture of samples by integrating topographic, spectroscopic, mechanical, and thermal properties of samples.

\subsection{Dynamic Light Scattering}

Dynamic light scattering (DLS), also called photon correlation spectroscopy and elastic light scattering [110,111], involves a table top instrument and is an easy-to-handle technique. Furthermore, the method is accurate, less time consuming, inexpensive, and data reproducible and allows analysis of high-molecular-weight samples. It is mainly used to evaluate the size and surface charge of NPs. Colloidal dispersed NPs can only be measured by Brownian motion [112]. It also has certain limitations such as aggregation and is not suitable for the analysis of nonspherical nanomaterials with heterogeneous size distributions. The working principle of the DLS involves screening the elastic scattering intensity of light from the Brownian motion of the sample. The particle size can be obtained from the motion-dependent auto correlation function of Einstein equation [113,114]. The salient features of DLS include measurement of samples ranging in size from $0.3 \mathrm{~nm}$ to $6 \mu \mathrm{m}$ and a minimum volume $10 \mu \mathrm{L}$ of sample suspension with an accuracy of $\pm 2 \%$ and a precision of $\pm 1 \%$. It can measure the zeta potential of colloidal, nanoparticulate, and macromolecular samples in the size range of $1 \mathrm{~nm}$ to $100 \mu \mathrm{m}$ with a minimum volume of $175 \mu \mathrm{L}$. It is frequently used to probe the behavior of complex fluids such as concentrated polymer solutions. It can be used to analyze a wide range of suspension concentrations (from $0.1 \mathrm{ppm}$ to $40 \% \mathrm{v} / \mathrm{v}$ ) depending on the sample type. 


\subsection{Electrophoretic Light Scattering (ELS)}

Electrophoretic light scattering (ELS) is a technique used to measure the electrophoretic mobility of particles in dispersion, or molecules in solution. This mobility is often converted to Zeta potential to enable comparison of materials under different experimental conditions. The basic principle of this instrument is electrophoresis, which is mainly based on electric charges, when electric field is applied into the dispersion, particles, or molecules are having net zeta potential will migrate towards the oppositely charged electrode with a velocity, known as the mobility, that is related to their zeta potential. Malvern Instruments offers equipment to measure the electrophoretic mobility of particles using electrophoretic light scattering. For example, The Zetasizer Nano provides a simple, fast, easy, and accurate way to measure zeta potential and free from cross contamination due to use of unique disposable capillary cell.

\section{6. $X R D$}

$\mathrm{XRD}$ is one of the best methods for characterization of the crystalline form of organic and inorganic materials. Particularly, the cubic and crystalline nature and purity of PtNPs can be measured. XRD is nondestructive, simple, highly sensitive, depth profile, table make, and user friendly. It also contains several application aspects such as pharmaceutical, glass, polymer, geological, and forensic and has been used to analyze the chemical composition by quantitative and qualitative measurements by measuring the degree of crystallinity and providing accurate information on the atomic arrangements at interfaces. The crystal structure describes the atomic arrangement, position, and intensity of the diffraction peaks. The wavelength of X-rays is on the atomic scale. Therefore, it is mainly used for probing the structure of nanomaterials. A single beam of X-rays is scattered by each atom in the powder sample. The scattered beams reflected by any crystal form many diffraction patterns. Where the X-rays scattered sample the maximum intensity of the peak at a particular angle. This peak reflects the structural and physicochemical characters of the crystal. The working principle of XRD follows Bragg's Law $[115,116]$. The unique pattern of the diffraction beam is compared with the reference database in the Joint Committee on Powder Diffraction Standards (JCPDS). Elemental composition of metal NPs is usually analyzed by EDS [117].

\subsection{Scanning Electron Microscopy (SEM)}

SEM is a versatile, nondestructive analytical method that involves a microscope with a large specimen chamber, with a working distance of $8.5 \mathrm{~mm}$, owing to a combination of inclined detectors and the sharp conical objective lens. SEM is used for surface and dimensional measurements of nano and micro structure analysis of samples and is a type of imaging technique. It is a valuable tool for the evaluation of material structure. It is fast and easy to operate and provides reliable data. In addition, SEM is applied in numerous fields such as biological science, biomolecules, biomedical fields, and material sciences. In biomedical sciences, it is primarily used to characterize cells and organ and tissues surfaces based on 3D images. It provides more information about the cell surfaces. The working principle of SEM is based on generation of electron beams that have magnetic properties. Their magnetic field interacts with the sample to produce secondary and backscattered electrons, which are used for detection [118-121]. The detection of transmitted electrons is very useful to study nanomaterials. Furthermore, the elemental composition and concentration of samples can be analyzed using SEM-EDX.

\subsection{TEM}

TEM is a common method and an indispensable tool for the characterization of NPs. This main advantage is the determination of the morphology, crystal structure, and size and the qualitative and quantitative analysis of prepared NPs and internalized NPs in cells or tissues [122-125]. Conventional TEM techniques are used to analyze the sample ubiquitously. However, this technique has certain 
limitations related to samples $>300 \mathrm{~nm}$ thick, only limited areas of which are screened; for particle size $>100 \mathrm{~nm}$, low magnification is achieved; TEM cannot characterize small-sized NPs (10-20 nm or less than $10 \mathrm{~nm}$ ); and sample preparation is destructive. TEM is classified based on applications like immune and energy filtered electron microscopy.

\subsection{AFM}

AFM is also called scanning force microscopy (SFM). It involves a small, powerful, high-speed, benchtop, and compact instrument. It is a potential tool for image analysis of biological samples on the nanometer scale; particularly, it is used to measure surface thickness of nanomaterials. This instrument works based on the interaction forces between the surface of the sample and tip of the cantilever. It has numerous applications in various fields divided into two categories: imaging and non-imaging. Three decades ago, AFM techniques were used for lipid membrane analysis [126]. AFM is also used to analyze biological samples and cascade-DNA images [127]. A major limitation of AFM is sample preparation for the study of biological sample. AFM is a type of scanning probe microscopy (SPM). The AFM tip contacts the surface of the sample, and lower and higher frictional forces are measured in this mode [128]. It is an innovative tool used in various fields such as nanotechnology, physics, chemistry, biology, and medicine. SPM is mainly used to construct 3D maps with nanostructural details of biological molecules, cellular components, and cells surfaces [129]. It is also used to characterize mechanical properties of cell membranes [130] and analyze viscoelasticity [131], stiffness of the cell membrane [132], cell adhesion [133], living cell [134], gene packaging material [135,136], mRNA expression [137], and immunological studies [138]. There are two types of SPM: scanning tunneling microscopy (STM) and near field scanning optical microscope (NSOM). STM is used in the industrial sector and for basic research to obtain atomic scale images of surfaces and to analyze the surface defects, molecule size, and aggregation to the surface. It works based on quantum mechanics and piezoelectric effects. NSOM is another type of SPM which uses a wavelength light source used as a scanning probe. This probe is used for scanning. It scans over the surface of material at a height of a few nanometers [139].

\subsection{EXAFS}

EXAFS is used to analyze the structural information of a sample, which is based on the X-ray absorption spectrum, and is mainly used for elemental analysis of inter atomic distance and structural disorders [140] as well as for other applications such as in natural science, biological science, and earth science. Furthermore, in contrast to other diffraction techniques, samples in all forms can be analyzed, such as solid, liquid, glass, gas, and crystalline samples. This flexibility is the main advantage for biological science analysis. Kossel [141] recorded the X-ray absorption spectrum using conventional and the se of synchrotron radiation as a source of high intensity of $X$-ray. It enhances the quality of data, but is time-consuming.

\section{Multifarious Applications of PtNPs}

The unique features of PtNPs, such as surface functionalities; size; size distribution; shape; porosity; surface area; composition; crystalline nature; agglomeration; and electro, catalytic, thermal, and plasmonic properties, make their application desirable in various fields (Figure 14). Recently, PtNPs have garnered a steadily growing interest for different biomedical applications such as antimicrobial agents, anticancer agents, targeted drug delivery, hyperthermia, photoablation therapy, bioimaging, and biosensing. Bimetallic NPs such as iron platinum (Fe-Pt) NPs possess unique chemical and magnetic properties such as chemical stability, superparamagnetization, high Curie temperature, high saturation magnetization, and high $\mathrm{X}$-ray absorption. These unique properties provide the potential of their application in hyperthermia treatment, as MRI contrast agents, in drug delivery, and as biosensors [142-159]. 


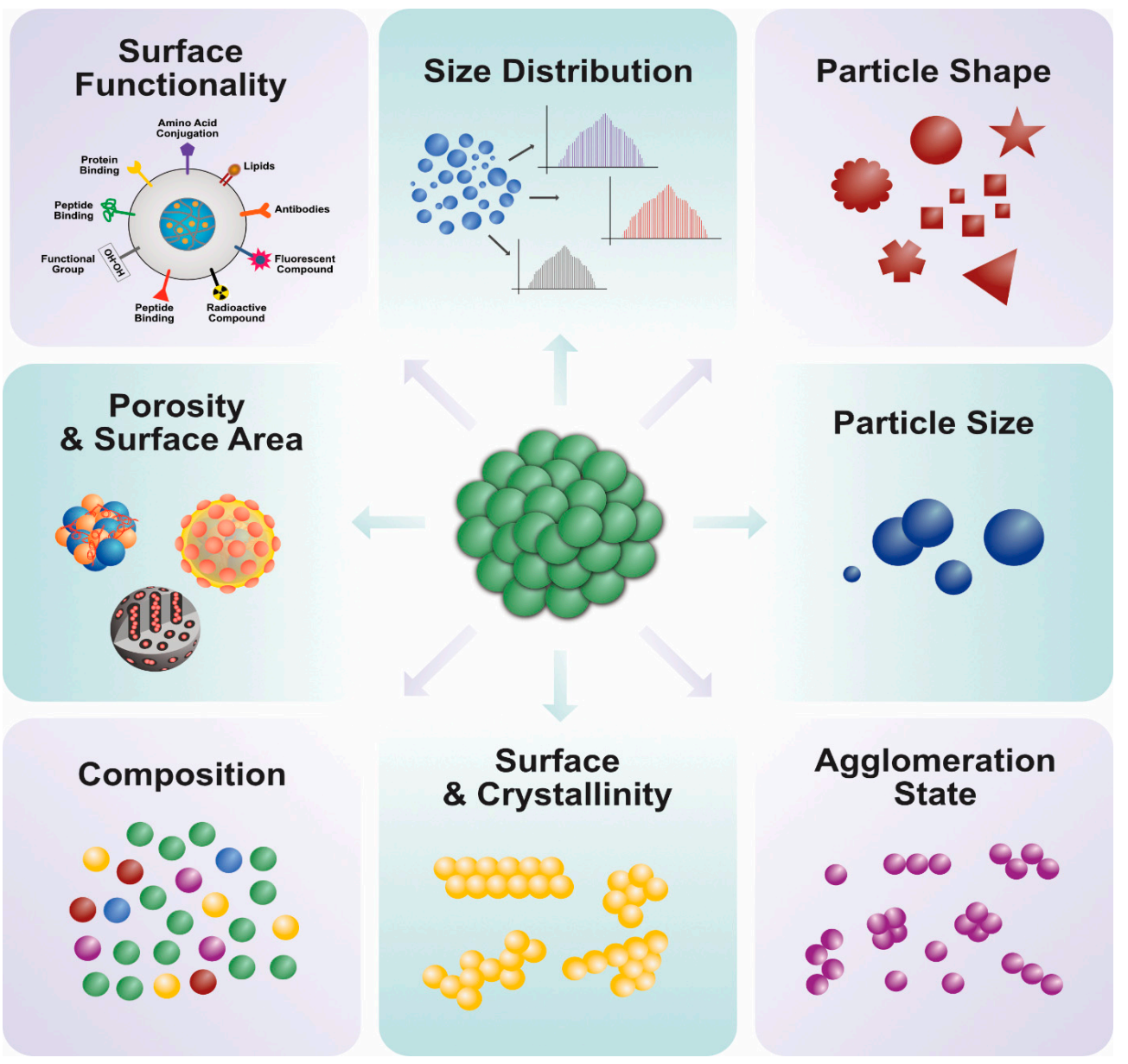

Figure 14. Physicochemical properties of platinum nanoparticles.

\section{Antibacterial Activity of Platinum Nanoparticle}

The current scenario shows paramount importance of PtNPs in human health and for the protection from various diseases caused by microorganisms. However, microorganisms are powerful and attain resistance to various antibiotics. Because of the recent increase in bacterial resistance, alternative therapeutic agents that are nontoxic to human beings but toxic to pathogenic microorganisms are urgently required. Therefore, the development of NP mediated antimicrobial agents is most warranted. Recently, several studies have focused on NP-based therapeutic agents against pathogenic bacteria. Metallic NPs such as, $\mathrm{Pt}, \mathrm{Ag}, \mathrm{Pd}, \mathrm{Cu}, \mathrm{Au}, \mathrm{ZnO}$, and $\mathrm{TiO}_{2}$ play a vital role in antibacterial activity against pathogens [160]. The antibacterial activity depends on NP morphology, size, and shape and also its surface charges. Most metallic $\mathrm{NPs}$ like $\mathrm{Ag}, \mathrm{Pt}, \mathrm{Au}, \mathrm{Pd}, \mathrm{ZnO}$, and $\mathrm{Cu}$ have a negative zeta potential and thus have potential cell damaging properties. Although PtNPs have a more negative zeta potential and cause severe damage to the cells, they show enhanced antibacterial activity [161]. Apigenin functionalized PtNPs exhibited significant antibacterial activity against Pseudomonas aeruginosa and Staphylococcus aureus (Figure 15). 


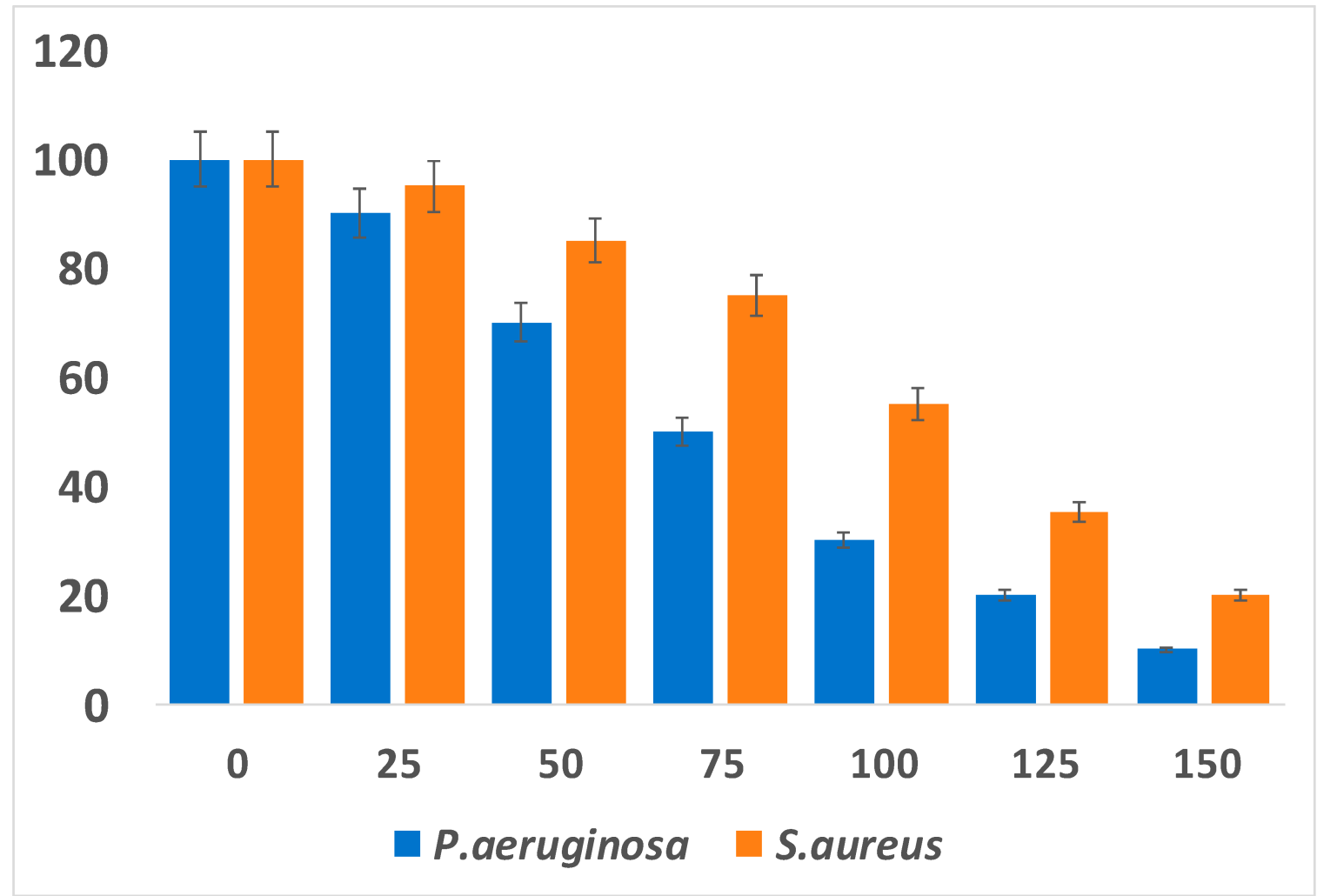

Figure 15. Antibacterial activity of PtNPs against Gram negative and Gram-positive bacteria. Effect of apigenin mediated synthesis of PtNPs on cell survival of P. aeruginosa and S. aureus was analyzed. All the test strains were incubated in the presence of different concentrations of PtNPs $(25-150 \mu \mathrm{g} / \mathrm{mL})$. Bacterial survival was determined at $24 \mathrm{~h}$ by a colony forming unit (CFU) assay. The results are expressed as the means \pm SD of three separate experiments, each of which contained three replicates.

Previously, Rosenberg et al. [162] demonstrated that platinum electrolysis products inhibit growth of Gram-negative bacterium Escherichia coli and the multiplication of cell. Four years later, they again demonstrated that the square planar form of platinum was highly effective against rat sarcomas. Ma et al. [163] reported that a combination of quaternary ammonium-based antibacterial monomers with colloidal PtNPs potentially inhibits Streptococcus mutans. Polyaniline/Ag-Pt nanocomposite inhibits growth of Staphylococcus aureus [164]. Palladium complexes of polyamide S-containing sulfones showed the highest antibacterial activity against Staphylococcus aureus and E. coli and antifungal activity against Aspergillums flavus and Candida albicans [165]. Bimetallic NPs (AuPt) with sizes ranging between 2 and $3 \mathrm{~nm}$ have potent antibacterial activity against human pathogenic organisms such as E. coli, Pseudomonas aeruginosa, Klebsiella pneumonia, and Salmonella choleraesuis [166]. These reports suggested that bacterial growth inhibition is correlated with ATP production and mitochondrial membrane potential. Another recent report described that five different shapes and sizes of polyvinylpyrrolidone-coated PtNPs ranging between 2 and $20 \mathrm{~nm}$ were used to examine the antibactericidal activity against $P$. aeruginosa. They observed that NPs less than $3 \mathrm{~nm}$ in size were toxic to P. aeruginosa even at low concentrations, whereas NPs $>3 \mathrm{~nm}$ in size showed no toxicity but only interacted with the bacterial membrane [167]. Two different sizes of PtNPs with PVP coating ranging between 5.8 and $57 \mathrm{~nm}$ were used to evaluate the antibacterial activity against E. coli and S. aureus. It was observed that the smaller NPs inhibited the proliferation of gram negative bacteria $E$. coli. These results agreed with those of a previous report [168]. Subsequently, Ahmed et al. [169] (2016) reported the antibacterial activity of PtNPs 2-5 $\mathrm{nm}$ in size against gram positive and gram negative bacteria. As a result, the PtNPs reduced bacterial cell viability through reactive oxygen species (ROS) production, led to membrane integrity loss, and also increased the survival rate of infected Zebra fish. Polyaniline/Pt-Pd nanocomposite shows 
potential antibacterial activity against Streptococcus and Staphylococcus species, E. coli, and Klebsiella spp. [170]. Platinum-PMMA nanocomposites (PtNCs) inhibit the cell viability of Streptococcus mutans and Streptococcus sobrinus [171]. Pt/Ag bimetallic NPs (BNPs) decorated on porous reduced graphene oxide (rGO) nanosheets exhibited increased antibacterial activity against $E$. coli on interfaces between metal compositions, rGO matrix, and bacteria. The release of nanocomposites led to a rapid release of silver ions, thus trapping the bacteria in the porous rGO matrix. Polyvinylpyrrolidone (PVP) as PVP/PtNP nanocomposites shows potential antibacterial activity against E. coli, Lactococcus lactis, and Klebsiella pneumoniae [172]. Biologically synthesized PtNPs using rind extract of the fruit of Garcinia mangostana showed antibacterial activity against Staphylococcus spp., Klebsiella spp., and Pseudomonas spp. (except Bacillus spp.). The highest activity was observed against Klebsiella spp. compared with other bacterial species.

\section{Antifungal Activity of Platinum Nanoparticles}

Commercial antifungal agents lead to side effects such as liver damage, nausea, renal failure, increase of body temperature, and diarrhea. At present, alternative therapy is required for recovery from fungal disease. Previously, Gardea-Torresdey et al. [81] reported silver NPs as having potential antifungal activity against spore-producing fungi. Recently, a study compared the antifungal activity of PtNPs and commercially available antifungal agents. The biofabricated PtNPs showed potential antifungal activity against different pathogenic fungi such as C. acutatum, C. fulvum, P. drechsleri, D. bryoniae, and P. capsici [94]. The persistence of the biopolymer mediated synthesized platinum nanocomposites (GKPtNPs) was assessed to analyze the antifungal activity against fungal strains such as $A$. parasiticus and $A$. flavus. They observed antifungal activity of the nanocomposite induced the morphology of the mycelia, membrane damage, increased the level of ROS, eventually leading to DNA damage and cellular death [173].

\subsection{Anticancer Activity of Platinum}

Cancer is a leading cause of death worldwide. According to the International Agency for Research on Cancer (IARC), the global cancer burden is estimated to have risen to 18.1 million new cases and 9.6 million deaths in 2018 (https://www.who.int/cancer). Every year, the number of cancer patients is increasing at an alarming level. It is projected that by 2030, approximately 13 million patients will be diagnosed with cancer and the estimated death rates are 13.1 million [174]. There are several conventional treatments used for the treatment of cancer such as chemotherapy, radiation, hormone therapy, and surgery. Although chemical treatment plays a major role in cancer therapy, chemotherapy is associated with some side effects. Radiation is end stage of therapy, and surgical therapy is associated with recurrence rate related to resection of tumors. Therefore, it is essential to develop alternative, simple, and effective therapy for prevention of cancer. NP mediated cancer therapy seems to be effective, simple, and free from undesired side effects.

Cisplatin (cis-[ $\left.\mathrm{PtCl}_{2}\left(\mathrm{NH}_{3}\right)_{2}\right]$, cis-diamminedichloridoplatinum(II)) and PtNPs have proven antitumor activity against various types of cancer cells. For instance, sarcoma 180 and leukemia L1210 cells were discovered by Barnett in the 1960 [175]; however, they involve dose-dependent toxicity and intrinsic or acquired drug resistance. According to Galanski et al (2005), platinum compound-based drugs have paved the way for cancer treatment, and $50 \%$ of cancer patients use platinum drugs for chemotherapeutic treatment [176]. A few decades ago, chemotherapeutic agents were used for treatment of several cancers. Most of these drugs are highly effective, but they also generate systematic toxicity and drug resistance to cancer cells [177]. Platinum derivatives like cisplatin, carboplatin, and oxaliplatin were used for treatment of cancer. All three drugs are square planar platinum (II) complexes surrounded by ligands: two amine ligands on the left side strong interaction with the platinum ion is called as non-leaving group and other two chloride ligands on the right side interaction with the platinum ion to form bonds with DNA bases [178]. Cisplatin is one of the major compounds used for the treatment of cancers such as small cell lung cancer, ovarian cancer, 
melanoma, lymphoma, myelomas, and colon and neck cancer [179]. It also used in the treatment of testicular cancer with a cure rate of above 95\% [180]. Different sized NPs $(<20,<100$, and $>100)$ have been used to analyze the toxicity in human colon carcinoma cell line (HT29). The results suggested that the toxicity effects depend upon the size of the PtNPs, but it is not due to the production of ROS [181]. Platinum ions were used as an anticancer therapeutic molecule with a similar strategy to cisplatin. Several reports suggested certain limitations of cisplatin such as nephrotoxicity [182], ototoxicity, neurotoxicity, hemolysis [183], and toxicity to gametogenesis [184]. Although chemist target platinum compound is considerably variation from structure activity relationship (SARs) based established nonclassical platinum compound such as poly platinum compounds, Pt (IV) prodrugs, complex with stereochemistry mechanisms, platinum-tethered intercalators, and monofunctional complexes, which is discerned from bifunctional cross link of classical compounds. The classical platinum anticancer agent, cisplatin, exerts its cytotoxic effect by selectively binding to the N7 atom in the purines of the DNA molecule and forms platinum-DNA adducts, which break the DNA double helical structure, impairing its replication and transcription $[185,186]$. These properties are exploited for the treatment of cancer and are used for the treatment of various types of cancers such as head, neck, brain, testicular, bladder [187], ovarian, or uterine cervical cancers [188]. However, platinum-based cancer therapy drugs generate some toxicity and side effects $[189,190]$. Previous studies have reported that PtNPs administrated to chicken embryos at 1-20 $\mu \mathrm{g} / \mathrm{mL}$ did not affect the growth and development of the embryo. They also activated the apoptosis in brain cells as well as decreased the proliferation, suggesting the role of PtNPs in brain cancer therapy [191].

In the past two decades, nanomedicine has been growing immensely for detection of tumor and drug delivery system [192]. However, biosynthesized NPs play a very vital role in the molecular interaction and cross biological barrier without distressing normal cells. The biologically synthesized PtNPs from Saccharomyces boulardii showed anticancer effects against two different cell lines-squamous carcinoma cell line A431 and luminal breast cancer cell line MCF7 [193]. Similarly, Sahin et al. [100] reported that biosynthesized PtNPs exhibited efficient antitumor activity against the MCF7 cell line. They induced apoptosis through G0/G1 cell cycle arrest. Subsequently, Ghosh et al. [194] evaluated the synergistic effect of anticancer activity using combined metallic NPs. The anticancer activity of combined NP (PtNPs-PdNPs) showed a 74.25\% refinement than that of individual metallic nanoparticle such as platinum (PtNPs-12\%) and palladium (PdNPs-33\%). In addition, early stage of apoptosis development was observed in HeLa cells. In vitro studies have demonstrated that PtNPs inhibited the growth of A549 cells in a dose-dependent manner, and the in vivo data showed that PtNPs at the mid and high doses effectively inhibited and delayed the growth of lung cancer in SCID mice [195]. PtNPs can potentially induce anticancer activity compared to chemotherapeutic drug, such as cisplatin by increasing the level of glutathione, superoxide dismutase activity, and malondialdehyde level, which is similar to treatment of hepatocellular carcinoma induced by diethylnitrosamine in rats [196]. Kutwin et al. [197] reported differential effects of PtNPs and cisplatin on viability of U87 glioblastoma multiforme (GBM) cells. The results showed that PtNPs have potential effects on cell viability and induce genotoxic and proapoptotic effects in U87 glioblastoma multiforme (GBM) cells comparable with cisplatin. Furthermore, NP-Pt decreased the weight and volume and induced pathomorphological changes of tumor tissue. Recently, Gurunathan et al. [198] demonstrated the anticancer properties of graphene oxide-green PtNPs (GO-PtNPs) on human prostate cancer cells (LNCaPs). GO-PtNPs increased the apoptosis and decreased the cell viability and proliferation by elevating ROS production. The increased ROS by GO-PtNPs caused membrane damage, mitochondrial dysfunction, and oxidative DNA damage.

\subsection{Cytotoxicity of PtNPs in Cancer and Non-Cancer Cells}

The unique physicochemical properties of NPs lead to their incorporation in many other applications [1]. Previously, several NPs were used in biomedical applications such as diagnostic assays [199], molecular imaging [200], implants [201], and drug delivery systems [202]. Recently, 
PtNPs have attracted great attention in the field biomedical applications such as nanomedicine [3], photothermal therapy [203], radiation dose enhancement [204], computed tomography (CT), and X-ray contrast [7]. The immense need of NP usage is accompanied by the corresponding increase in human exposure to these novel nanomaterials. In this area, nanotoxicology was founded to investigate the safety of nanomaterials and their usage in biological systems [205]. NP toxicity is determined by several aspects such as size, shape, surface area, catalytic activity, charges, and chemical composition of NP [206] and also depends on various shapes and method of entry into the cells.

Commonly, toxicity analysis is carried out by two ways - in vivo and in vitro. These are all methods involved depends on system of toxicity. Previously, several studies documented size-based toxicity of NPs using various metallic NPs. Different metal NPs were employed for biomedical applications; particularly, gold and silver were used extensively for nanotoxicology investigation, but limited studies investigated the cytotoxicity of PtNPs. PtNPs were exposed two different types of cell lines, human endothelial cells and lung epithelial cells, for the toxicity analysis [207]. The results from this study indicated that both cells can uptake PtNPs, but there is no induction of ROS-induced cytotoxicity. The cytotoxicity of PtNPs is also depends on various shapes of the particles, the particle shape can determine the entry of particle and potentiation of cytotoxicity. The entry and effect of cisplatin and PtNPs are shown in Figure 16.

However, lung inflammation was observed in the respiratory tract. The cytotoxic nature of PtNPs was analyzed using tea capped PtNPs in cervical cancer cells (SiHa). The results showed that tea capped PtNPs influenced cell viability, nuclear morphology, and cell cycle distribution and inhibited proliferation of SiHa cells [208]. Onizawa et al. [209] synthesized polyacrylate stabilized PtNPs. These NPs were intranasally administered to DBA/2 mice exposed to cigarette smoke. The results revealed that PtNPs inhibited cigarette smoke induced depletion of antioxidant capacity, NF- $\mathrm{B}$ activation, and neutrophilic inflammation in the lungs of mice. Gao et al. [210] analyzed cytotoxic properties of FePt@CoS(2) yolk-shell nanocrystals in HeLa cells; the results showed that FePt@CoS(2) yolk-shell nanocrystals displayed much lower IC $(50)(35.5 \mathrm{ng} / \mathrm{mL})$ than cisplatin $(230 \mathrm{ng} / \mathrm{mL})$. Toxicity against human breast cancer cells was reported using folic acid and poly(vinyl pyrrolidone) functionalized PtNPs using sodium borohydride in the presence of capping agents. The cytotoxicity was potentially higher than that of PVP-capped NPs [211]. Asharani et al. [212] reported 5-8 nm polyvinyl coated PtNPs that entered human cells by diffusion led to an increase in DNA damage, inhibition of proliferation of cells, and induction of activation of p21, leading to proliferating cell nuclear antigen-mediated growth arrest and apoptosis.

The effects of two different sizes of polyvinylpyrrolidone-coated coated PtNPs (5.8 nm and $57 \mathrm{~nm})$ were analyzed on primary keratinocytes. Larger sizes of particles showed decreasing cell metabolism, but there was no significant effect on cell viability or migration, whereas smaller NPs exhibited more deleterious effects on DNA stability, and these triggered caspases [213]. Fibroblast cells L929 or macrophages RAW264 treated with PtNPs exhibited loss of cell viability and DNA damage, and PtNPs also inhibited matrix metalloprotease (MMP) activity [214]. Biologically synthesized PtNPs using pomegranate extract showed cytotoxic effects against MCF-7 cell line by decreasing cell viability and increasing apoptosis and DNA damage [100]. Two different types of PtNPs-NG-Pt NPs and MG-Pt NPS - with an average size of $15 \mathrm{~nm}$ and $8.5 \mathrm{~nm}$, respectively, induced cytotoxicity in C2C12 cells by decreasing cell viability and increasing ROS generation. Furthermore, these PtNPs increased the expression of caspases 3 and 9 and also promoted the expression of proinflammatory proteins such as TNF- $\alpha$, TGF- $\beta$, and NF- $\mathrm{B}$. Among these PtNPs, smaller-sized particles significantly increased cytotoxicity [215]. PtNPs induced apoptosis in Raw 264.7 cells by altering cell morphology and density and also increased apoptosis, activation of caspases 3 and 7, and DNA fragmentation [216]. Wei et al. [217] reported that polyethylene glycol-graphene quantum dots-Pt (GPt) with an average size of $5 \mathrm{~nm}$ sensitize oral squamous cell carcinoma (OSCC) in both normoxic and hypoxic conditions. GPt exhibits a strong inhibitory effect on tumor growth with less systemic drug toxicity and helps in combating hypoxia-induced chemoresistance in an OSCC xenograft mouse tumor model. Biologically 
synthesized PtNPs using leaf extract of Azadirachta indica altered cellular responses of HEK293 cells. PtNPs induce cytotoxicity of HEK293 cells in a dose- and time-dependent manner by increasing caspase 3 expression, depolarization of mitochondrial membrane potential, and DNA fragmentation [218]. Peptides stabilized with average diameters of $2.5 \mathrm{~nm}$ showed more potent toxicity against hepatic cancer cells (HepG2) than against other cancer cells and noncancerous liver cells compared to cisplatin [219]. A study reported the effect of novel platinum nanocomposite (PtNCP) beads on OSCC cell lines, and HSC-3-M3 cells were injected into nude mice both in vitro and in vivo. The results depicted that treatment with PtNCP beads suppressed tumor growth and identified increasing pathological necrotic areas. In vitro data suggest that PtNCP beads inhibited cell viability of HSC-3-M3 cells in a dose-dependent manner and induced cytotoxicity with increased leakage of lactate dehydrogenase [220]. Recently, Gurunathan et al. [101] reported that apigenin functionalized PtNPs exhibited potential cytotoxicity, genotoxicity, and proinflammatory responses in human monocytic cell line (THP-1) by increasing the levels of lactate dehydrogenase, generation of ROS, and production of malondialdehyde, nitric oxide, and carbonylated proteins and also increased apoptosis and oxidative DNA damage. Finally, PtNPs increased the expression of various proinflammatory cytokines such as interleukin- $1 \beta$ (IL-1 $\beta)$, IL-6, IL-8, tumor necrosis factor- $\alpha$ (TNF- $\alpha)$, granulocyte-macrophage colony-stimulating factor (GM-CSF), and monocyte chemoattractant protein 1 (MCP-1). All these findings substantially confirmed that PtNPs can induce cytotoxicity in both cancer and noncancer cells. Cisplatin and PtNPs are able to induce cytotoxicity differentially in various type of cancer cells (Figure 17).



Figure 16. Diagrammatic sketch representing the possible mechanism of platinum nanoparticle induced cytotoxicity in cancer cell lines. 

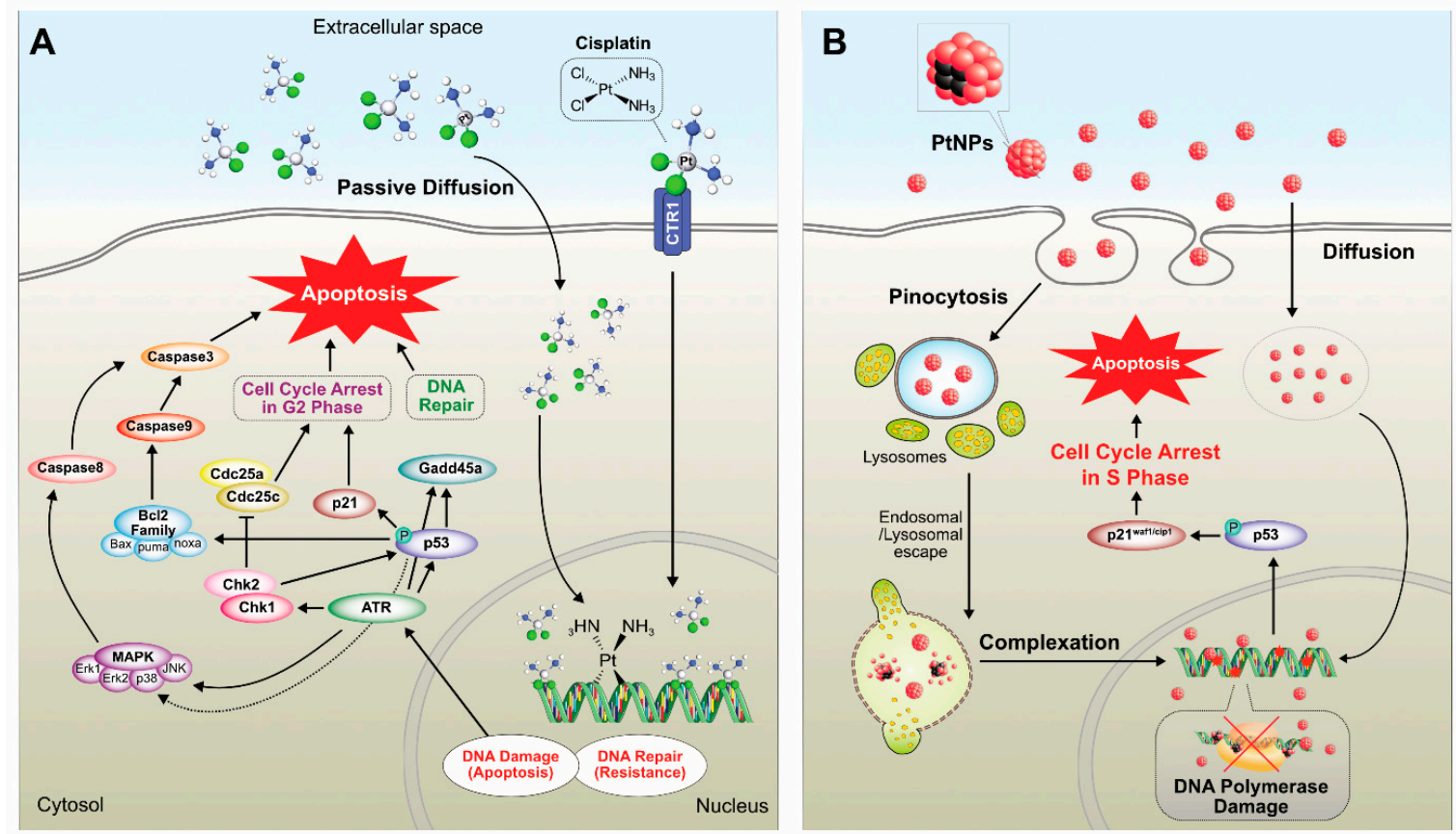

Figure 17. Schematic illustration showing the differential effect of cisplatin (A) and platinum nanoparticles $(\mathbf{B})$ in cancer cells.

\section{In Vivo Toxicity of PtNPs}

Asha Rani et al. synthesized different type of nanoparticles with various sizes (silver 3-10 nm, platinum 5-35 nm, and gold NPs 15-35 nm) using polyvinyl alcohol as capping agent and investigated the impact synthesized NPs. Polyvinyl alcohol capped silver NPs exhibited significant toxicity in Zebrafish embryos followed by PtNPs. No significant toxicity was observed with gold NPs. Silver and PtNPs revealed that AgNPs and PtNPs showed size-dependent toxicity in aquatic zebrafish embryos [221]. Recently, Claudia et al. [222] reported that citrate coated PtNPs increased the toxicity of mammalian liver cell line HepG2 at higher concentrations of PtNPs, whereas lower concentrations of PtNPs induced multiple stress response factors. PtNPs a caused size and dose-dependent effect on DNA strand breaks in human colon carcinoma cells (HT29) and increased the content of platinum in DNA $[181,223]$. Mice treated with PtNPs showed proinflammatory responses, and PtNPs increased various proinflammatory cytokines, such as IL-1, TNF-alpha, IL-6, IL-2, IL-12, IL-4, and IL-5, and concomitantly decreased intracellular levels of GSH [33]. Keratinocytes and mammary breast cells were incubated with folic acid functionalized PtNPs with an average size of 2-3 nm and showed significant toxicity toward cancer rather than non-cancer cells, suggesting that these PtNPs specially target cancer cells [224]. A comparative toxicity study between two different type of PtNPs such as sub-nanosized platinum particles (snPt) and nano-sized PtNPs was performed in the mouse liver. After intravenous administration of snPt into mice, the mice showed acute hepatic injury and increased levels of serum markers of liver injury and inflammatory cytokines. In contrast, administration of nano-sized platinum particles did not produce these abnormalities. Therefore, snPts have the potential to induce hepatotoxicity [225]. Further, authors demonstrated that single intravenous doses of snPt1 in in mice induce necrosis of tubular epithelial cells and urinary casts in the kidney, without causing any effect on lung, spleen, and heart, and cause a dose-dependent elevation of blood urea nitrogen, which is an indicator of kidney damage, whereas snPt induced significant cytotoxicity [225].

\subsection{Use of PtNPs in Combination Therapy}

PtNPs are potential drugs for combination therapy because of their salient features of accumulation of ROS and ROS scavenging properties in the treatment of complex diseases such as cancer and 
neurodegeneration. Combination therapy strategies have been used to promote synergetic efficacy and overcome the resistance of platinum drugs. For instance, the combination of platinum drugs and imaging agents allows the distribution of drug-loaded NPs inside the body and the tumor. Combination therapy has exhibited reduced systemic toxicity in comparison to either photothermal treatment or chemotherapy alone. Further, PtNPs can be exploited proper functionalization different reducing agents. Generally, platinum-based drugs are used in the treatment of cancer, including ovarian, head and neck, and lung cancer [226]. Platinum-based drugs yield positively charged, reactive aquated species that subsequently can form stable DNA-adducts and eventually cause cell death [226]. Nanocapsules of cisplatin enter the cells more efficiently than free compounds. Increased levels of platinum accumulation cause cisplatin-DNA-adduct formation in IGROV-1 cells [227]. A combination of PtNPs with irradiation by fast ions effectively enhances the strong lethal damage to DNA [204]. Nanocomposite S-containing platinum and titanium NPs exhibit very high photodynamic efficiency under a mild ultraviolet radiation in human cervical cancer cells. This combination potential seems to be more effective and a promising candidate in cancer treatment than $\mathrm{TiO}(2)$ and $\mathrm{Au} / \mathrm{TiO}(2) \mathrm{NPs}$ [228]. Bifunctional self-assembled NPs with a platinated fluorophore core with ultralow radiative transition synergistically induce photodynamic and photothermal therapy with tumor ablation through the generation of both singlet oxygen and the photothermal effect [229]. Multifunctional nano-platforms consist of iron-PtNPs (FePt NPs) with a polypyrrole (PPy) coating as a novel agent for combined photothermal therapy (PTT) and photoacoustic imaging (PAI). The obtained PPy-coated FePt NPs (FePt@PPy NPs) showed excellent biocompatibility and photothermal stability and high near-infrared (NIR) absorbance for the combination of PTT and PAI [230]. FePt-Cys NPs (FePt-Cys NPs) induced a burst of ROS, which suppressed the antioxidant protein expression and induced cell apoptosis through activation of the caspase system and impairment of DNA damage repair [231].

\subsection{Biomedical Applications of PtNPs}

PtNPs are used for various applications such as electro catalysts and catalytic converters, magnetic nanopowders, polymer membranes, cancer therapy drugs, coatings, plastics, nanofibers, and textiles (Figure 18). Herein, briefly, we discuss the biomedical applications of PtNPs. For instance, silica aerogel-supported PtNPs (SAP) were employed as fillers for preparing a self-humidifying Nafion-based composite membrane to enable the operation of PEMFCs without humidification subsystems. The synthesized SAPs were found to enhance the water adsorption and self-humidifying ability of the membrane because of their high surface areas and hydrophilic surfaces [232]. Four decades ago, thousands of new platinum drugs were synthesized and evaluated for their anticancer applications. However, only a small number of drugs were approved for marketing. In the past decades, more attention has been paid to the use of drug delivery and drug formulation methods of nanoplatin, lipoplatin, aeroplatin, and AP5346. The potential applications of nanocarriers for platinum drugs are prolonged drug circulation, cellular internalization of drugs, and multiple functional potential [233]. Platinum-based NPs act as a multidrug. They have a wide range of applications including cancer therapy, drug delivery, tumor targeting, co-encapsulation of therapeutic agents, and controlled release [233]. Drug delivery systems consist of two mechanisms-passive and active. Passive target systems focus on enhanced permeability and retention. The EPR system was described by Maeda and Mastumura [234,235], where they analyzed the accumulation of NPs in neoplastic tissues, which enhance the permeability and retention of NPs. The two essential characteristics of EPR, leaky vasculature and impaired lymphatic drainage, were characterized in solid tumor tissues [236,237]. Previously, several authors have reported that EPR effects increase the drug absorption as well as prolong drug retention $[236,238,239]$. Several nanocarriers have been developed for tumor-targeted drug delivery systems with different sizes and shapes of NPs. 


\section{Photothermal Therapy \& Radiotherapy}

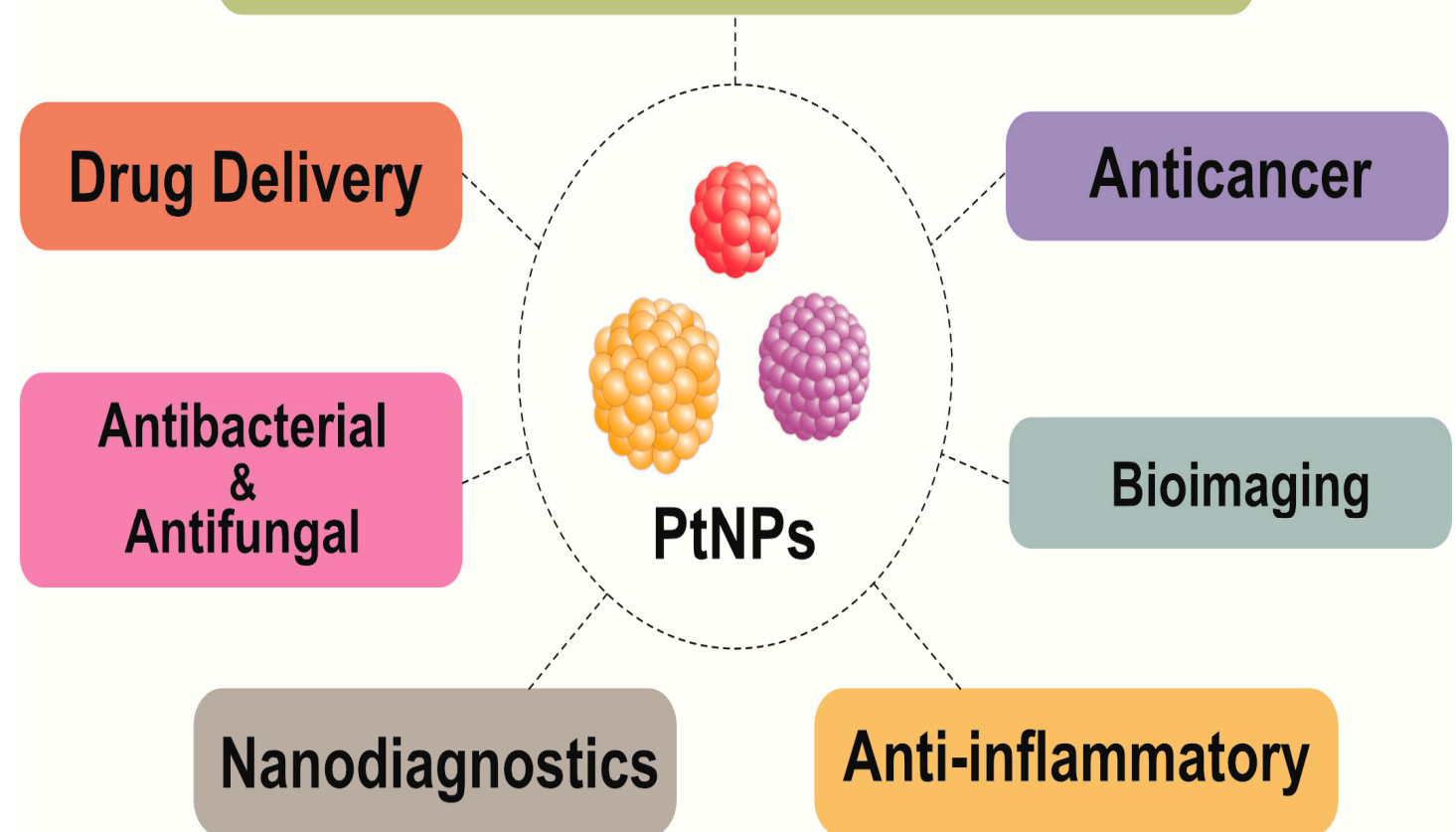

Figure 18. Multifarious applications of platinum nanoparticles.

However, the EPR effect enhances the tumor targeting of NPs. Several other parameters also influence the accumulation of NPs in tumors. Commonly, the put off blood circulation of NPs is prior to archive the successful drug delivery. Several polymers have been used as coating materials. PEG is frequently used as a coating material because of its size of $<100 \mathrm{~nm}$, high surface density, less accumulation in liver and spleen cells, reduced interaction with blood cells [240], and quick elimination of particles from circulation [241]. PEG has a prolonged blood circulation time, high tumor targeting capability, and improved tumor therapeutic efficiency [242]. Passive targeting is the accumulation of NPs in tumor cells, but the uptake of NPs by cancer cells through active targeting is facilitated through receptor or surface membrane proteins expressed on targets cells. A specific interaction between the ligands on surfaces of NPs and receptors expressed on the tumor-associated cells may facilitate the internalization of NPs through receptor-mediated endocytosis. Several targeting ligands have been used to actively target NPs including antibodies, antibody fragments, peptides, proteins, aptamers, and small molecules such as folic acid. Antibodies are used in nuclear medicine for diagnostic purposes and therapeutic applications. Antibodies are the target ligands for NPs because of their high selectivity, specificity, and specific cell type based on surface antigens [243]. Monoclonal antibody-mediated NP drug delivery systems involve human epidermal growth factor (HER2) 2, epidermal growth factor receptor (EGFR), transferring receptor (TfR), and prostate specific membrane antigen (PSMA). EGFR is a part of the ErbF family of receptors and is expressed in normal cells and over expressed in malignancy of epithelial cancer cells. Heparin-DDP (EHDDP) NPs drastically raise the intracellular concentration of platinum and Pt-DNA adducts in EGFR, over expressing non-small-cell lung cancer H292 cells. In vivo studies have also shown an increase in antitumor activity and improvement in pharmacokinetics and biodistribution with the conjugation of EGFR. Peptides are extensively used for targeting ligands based on their properties such as size, immunogenicity, stability, low cost, and conjugation properties. Different types of peptides have been used for specially binding to different targets on tumor cells such as small tripeptide RGD, which has a high affinity for $\operatorname{Rv} \beta 3$ and $\operatorname{Rv} \beta 5$ integrins that are overexpressed in tumor cells [244]. Cyclic pentapeptide c enhanced the cytotoxicity of $\mathrm{Pt}$ (IV) NPs in PC3 and DU145 cells, but there was no enhancement observed in MCF7 cells. Folic acid 
is a small-molecular-weight molecule with more innate advantages such as scalability, reproducibility, easy conjugation process, low immunogenicity, low affinity, and a wide diversity [245]. Folate receptors (FR $\alpha$ and $\beta$ ) are also associated with membranes that are capable of transporting folate into the cell [246]. FR is upregulated in several human cancers such as ovarian, breast, endometrial, renal, lung, and colon cancers. Its expression is minimal in normal tissues [247,248]. As a result, the folate receptor is an attractive target ligand for anticancer agents [248]. Over $90 \%$ of FR- $\alpha$ is expressed in ovarian cancers [249], whereas FR- $\beta$ is expressed in activated macrophages and malignant hematopoietic cells [250]. Previously, Dhar et al. [251] reported that folate Pt (IV)-SWNT conjugates showed higher cellular uptake in FR(+) JAR cells than that in FR(-) NTera-2 cells and observed higher cytotoxicity compared with that of cisplatin. Aptamers are short oligonucleotide ligands with different folding structures which can bind to specific biological targets [252]. The synthesized PSMA targeting aptamer functionalized Pt (IV) prodrug PLGA-PEG NP (Pt-NP-Apt) transport to cisplatin to prostate cancer cells. Pt-NP-Apt explained the in order to magnitude over effective than that of free cisplatin in PSMA+ LNCaP cells [253]. Cascade the Pt-NP-Apt showed equivalent antitumor efficacy in prostate cancer at $1 / 3$ the dose of cisplatin and reduced accumulation of Pt in kidneys [254].

\section{Conclusions and Future Perspectives}

Platinum plays a crucial role in industrial applications such as a catalyst in fuel cells and in biosensors. Recently, Pt-based nanomaterials have attracted interest in both academic and industrial fields because of their unique features and function as nanocarriers, nanozymes, and nanosensors for diagnostic purposes. In this review, we discussed various methods for the synthesis of PtNPs including physical, chemical, and biological methods and provided a detailed account of biological methods. For the past decade, considerable progress has been made in the synthesis of monodispersed and well-defined structures of PtNPs with sizes ranging from 1.2 to several nm. Furthermore, we discussed the working principles and application of analytical techniques used for characterization of NPs. More importantly, we discussed the toxicological effect, biomedical applications, and use of PtNPs in combination therapy. For a long time, Pt-based materials have played a critical role in clinical research to overcome the undesired side effects of chemo- and radiation therapy. Thus, the diagnostic and medical industries are exploring the possibility of using PtNPs as a next-generation anticancer therapeutic agent. Although, biologically prepared nanomaterials exhibit high efficacy with low concentrations, several factors still need to be considered for clinical use of PtNPs such as the source of raw materials, the method of production, stability, solubility, biodistribution, controlled release, accumulation, cell-specific targeting, and toxicological issues to human beings. The development of PtNPs as an anticancer agent is one of the most valuable and warranted approaches for cancer treatment. The future of PtNPs in biomedical applications holds great promise, especially in the area of disease diagnosis, early detection, cellular and deep tissue imaging, drug/gene delivery, as well as multifunctional therapeutics. Furthermore, to overcome the obstacles in exclusive multidrug resistance, multifunctional PtNPs need to be designed for diagnosis and targeting and as nanocarrier and phototherapeutic agents. The current emphasis of molecular medicine is to develop more novel tools, which can be used for early-stage disease diagnosis and long-term availability in the cellular system. Integration of nanomaterials, especially PtNPs, could extend the construction of the theragnostic platform, which combines therapeutics with diagnostics, to make the diagnosis processes more simple and rapid and less invasive. Furthermore, progressive development of novel nanocomposites containing PtNPs with multifunctional modalities could lead to better ways to use PtNPs as nano-theragnostic entities in biomedicine.

As the usage of PtNPs shows immense potential in the medical field, various new modalities need to be developed. Although various methods are available to prove the efficacy of nanomaterials, the synergistic effects of PtNPs and low concentration of anticancer drugs on anticancer activity/tumor reduction are still obscure. Therefore, more studies are required to explain the synergistic effect of PtNPs with anticancer drugs at a single time point. These studies could provide an understanding 
of the mechanisms and efficiency of the synergistic effect of two different agents or multiple agents; thus, they would help to develop a novel system bearing multiple components with synergistic effects for the treatment of various types of cancer. Although PtNPs have been focused on for therapeutic purposes, further research is required in animal models along with multicenter studies to confirm the mechanisms and to gain a comprehensive picture of biocompatibility vs. toxicity of PtNPs. Finally, if we succeed in all these studies, it would help the researchers of the nanoscience and nanotechnology community to develop safer, biocompatible, efficient cancer or antiangiogenic agents containing PtNPs. In future, multifunctional PtNPs would be an attractive platform for biomedical applications and may change the business model of pharmaceutical industries.

Author Contributions: J.-H.K. and S.G. came up with the idea and participated in writing of the manuscript. M.J. performed all literature surveys, the interpretation of literature and drawn model figures. M.Q. and M.-H.K. performed drawn all figures. All authors read and approved the final manuscript.

Funding: This study was funded by Konkuk University in 2018.

Acknowledgments: Although we are the authors of this review, we would never have been able to complete it without the great many people who have contributed to the field of platinum nanoparticles research. We owe our gratitude to all those researchers who have made this review possible. We wish to thank all the investigators who have contributed to the field of synthesis, characterization and biomedical application of platinum nanoparticles. We have cited as many references as permitted and apologize to the authors of those publications that we have not cited due to limitation of references.

Conflicts of Interest: The authors declare no conflict of interest.

\section{Appendix A}

Table A1. Synthesis of PtNPs using various parts of biological templates and their sizes and shapes.

\begin{tabular}{|c|c|c|c|c|}
\hline Name of the Organism & Parts Uses & Size (nm) & Shape & Ref. \\
\hline \multicolumn{5}{|l|}{ Bacteria } \\
\hline Desulfovibrio vulgaris & $\begin{array}{c}\text { Periplasmic } \\
\text { space/cellular surface }\end{array}$ & & & {$[71]$} \\
\hline Acinetobacter calcoaceticus & Intracellular & $2-3.5$ & Cuboidal & {$[72]$} \\
\hline \multicolumn{5}{|l|}{ Fungi } \\
\hline F. oxysporum & Extracellular & $10-50$ & $\begin{array}{l}\text { triangle, hexagons, square, } \\
\text { rectangles }\end{array}$ & [74] \\
\hline Neurospora Crassa & Intracellular & $\begin{array}{l}2-3,4-35,7-76 \\
\text { and } 20-110\end{array}$ & $\begin{array}{c}\text { Quasi spherical, single } \\
\text { crystalline and round nano } \\
\text { aggregates }\end{array}$ & [80] \\
\hline \multicolumn{5}{|l|}{ Plants } \\
\hline Doipyros kaki & Leaf & $2-12$ & & [82] \\
\hline Fumariae herba & Whole & 30 & Hexagonal and pentagonal & [83] \\
\hline Anacardium occidentale & Leaf & 100 & Irregular rod & [84] \\
\hline Azadirachta indica & Leaf & $5-50$ & Small and large sphere & [85] \\
\hline Piper betle $\mathrm{L}$. & Leaf & $2-0.4$ & Spherical & [86] \\
\hline Ocimun sanctum & Leaf & 23 & Irregular & [87] \\
\hline Phoenix dactylifera & Fruit & $1.3-2.6$ & Spherical & [91] \\
\hline Lantana camara & Leaf & 35 & Spherical & [93] \\
\hline Prunus $x$ yedoensis & Gum & $10-20$ & Circular & [94] \\
\hline Camellia sinensis & Leaf & $30-60$ & Flower & [95] \\
\hline Antigonon leptopus & Whole plant & 5-190 & Spherical & [96] \\
\hline B. prionitis & Leaf & $1-2$ & Monodispersed & [97] \\
\hline \multirow[t]{2}{*}{ Punica granatum } & Peel & $16-23$ & Spherical & [98] \\
\hline & Pomegranate & 20.12 & Spherical & [100] \\
\hline
\end{tabular}


Table A1. Cont.

\begin{tabular}{|c|c|c|c|c|}
\hline Name of the Organism & Parts Uses & Size $(\mathrm{nm})$ & Shape & Ref. \\
\hline \multicolumn{5}{|l|}{ Algae } \\
\hline Padina gymnospora & & 25 & Octahedral & {$[172]$} \\
\hline \multicolumn{5}{|l|}{ Bacteria } \\
\hline Saccharomy cesboulardii & Intracellular & $80-150$ & & {$[193]$} \\
\hline \multicolumn{5}{|l|}{ Plants } \\
\hline Eichhornia crassipes & Leaf & 3.74 & Spherical & {$[255]$} \\
\hline Quercus glauca & Leaf & $5-15$ & Spherical & {$[256]$} \\
\hline Bacopa Monnieri & Leaf & $5-20$ & Spherical & {$[257]$} \\
\hline Cochlospermum gossypium & Tree-Gum & 2.4 & Spherical & {$[258]$} \\
\hline \multicolumn{5}{|l|}{ Algae } \\
\hline Plectonema boryanum UTEX 485 & Cell extract & $<300$ & Spherical & {$[259]$} \\
\hline \multicolumn{5}{|l|}{ Bacteria } \\
\hline Calothrixv cyanobacteria & $\begin{array}{l}\text { Intracellular and } \\
\text { extracellilar }\end{array}$ & 3.2 & & {$[260]$} \\
\hline \multicolumn{5}{|l|}{ Plants } \\
\hline Pinus resinosa & Bark & $6-8$ & Irregular & {$[261]$} \\
\hline Gloriosa superb & Tuber & $0.83-3$ & Spherical & {$[262]$} \\
\hline Terminalia chebula & Fruit & $<4$ & Spherical & {$[263]$} \\
\hline Cacumen platycladi & Whole plant & $2.4-0.8$ & spherical & {$[264]$} \\
\hline
\end{tabular}

\section{References}

1. Khan, I.; Saeed, K.; Khan, I. Nanoparticles: Properties, applications and toxicities. Arab. J. Chem. 2019, 12, 908-931. [CrossRef]

2. Nie, Z.; Petukhova, A.; Kumacheva, E. Properties and emerging applications of self-assembled structures made from inorganic nanoparticles. Nat. Nanotechnol. 2010, 5, 15. [CrossRef] [PubMed]

3. Pedone, D.; Moglianetti, M.; De Luca, E.; Bardi, G.; Pompa, P.P. Platinum nanoparticles in nanobiomedicine. Chem. Soc. Rev. 2017, 46, 4951-4975. [CrossRef] [PubMed]

4. Azharuddin, M.; Zhu, G.H.; Das, D.; Ozgur, E.; Uzun, L.; Turner, A.P.F.; Patra, H.K. A repertoire of biomedical applications of noble metal nanoparticles. Chem. Commun. 2019, 55, 6964-6996. [CrossRef] [PubMed]

5. Shimomura, M.; Sawadaishi, T. Bottom-up strategy of materials fabrication: A new trend in nanotechnology of soft materials. Curr. Opin. Colloid Interface Sci. 2001, 6, 11-16. [CrossRef]

6. Johnstone, T.C.; Suntharalingam, K.; Lippard, S.J. The Next Generation of Platinum Drugs: Targeted Pt(II) Agents, Nanoparticle Delivery, and Pt(IV) Prodrugs. Chem. Rev. 2016, 116, 3436-3486. [CrossRef] [PubMed]

7. Wang, Z.; Chen, L.; Huang, C.; Huang, Y.; Jia, N. Albumin-mediated platinum nanocrystals for in vivo enhanced computed tomography imaging. J. Mater. Chem. B 2017, 5, 3498-3510. [CrossRef]

8. Doherty, R.E.; Sazanovich, I.V.; McKenzie, L.K.; Stasheuski, A.S.; Coyle, R.; Baggaley, E.; Bottomley, S.; Weinstein, J.A.; Bryant, H.E. Photodynamic killing of cancer cells by a Platinum(II) complex with cyclometallating ligand. Sci. Rep. 2016, 6, 22668. [CrossRef]

9. Huang, X.; Zhao, Z.; Fan, J.; Tan, Y.; Zheng, N. Amine-assisted synthesis of concave polyhedral platinum nanocrystals having $\{411\}$ high-index facets. J. Am. Chem. Soc. 2011, 133, 4718-4721. [CrossRef]

10. Tsung, C.-K.; Kuhn, J.N.; Huang, W.; Aliaga, C.; Hung, L.-I.; Somorjai, G.A.; Yang, P. Sub-10 nm platinum nanocrystals with size and shape control: Catalytic study for ethylene and pyrrole hydrogenation. J. Am. Chem. Soc. 2009, 131, 5816-5822. [CrossRef]

11. Miyake, M.; Miyabayashi, K. Shape and size-controlled Pt nanocrystals as novel catalysts. Catal. Surv. Asia 2012, 16, 1-13. [CrossRef]

12. Schmidt, E.; Vargas, A.; Mallat, T.; Baiker, A. Shape-selective enantioselective hydrogenation on Pt nanoparticles. J. Am. Chem. Soc. 2009, 131, 12358-12367. [CrossRef] [PubMed] 
13. Li, Y.; Somorjai, G.A. Nanoscale advances in catalysis and energy applications. Nano Lett. 2010, 10, $2289-2295$. [CrossRef] [PubMed]

14. Madsen, A.T.; Ahmed, E.H.; Christensen, C.H.; Fehrmann, R.; Riisager, A. Hydrodeoxygenation of waste fat for diesel production: Study on model feed with Pt/alumina catalyst. Fuel 2011, 90, 3433-3438. [CrossRef]

15. Lee, I.; Delbecq, F.; Morales, R.; Albiter, M.A.; Zaera, F. Tuning selectivity in catalysis by controlling particle shape. Nat. Mater. 2009, 8, 132-138. [CrossRef]

16. Kliewer, C.J.; Somorjai, G.A. Structure effects on Pyridine hydrogenation over Pt (111) and Pt (100) studied with sum frequency generation vibrational spectroscopy. Catal. Lett. 2010, 137, 118-122. [CrossRef]

17. Kasem, K.K. Role of Platinum in Photoelectrochemical Studies Related to Solar Energy Harvesting. Platin. Met. Rev. 2012, 56, 221-228. [CrossRef]

18. Kumakiri, I.; Diplas, S.; Simon, C.; Nowak, P. Photocatalytic membrane contactors for water treatment. Ind. Eng. Chem. Res. 2011, 50, 6000-6008. [CrossRef]

19. Li, Y.; Zhang, K.; Peng, S.; Lu, G.; Li, J.S. Photocatalytic hydrogen generation in the presence of ethanolamines over Pt/ZnIn2S4 under visible light irradiation. Mol. Catal. A Chem. 2012, 363, 354-361. [CrossRef]

20. McNamara, K.; Tofail, S.A.M. Nanoparticles in biomedical applications. Adv. Phys. 2017, 2, 54-88. [CrossRef]

21. Yoshihisa, Y.; Honda, A.; Zhao, Q.L.; Makino, T.; Abe, R.; Matsui, K.; Shimizu, H.; Miyamoto, Y.; Kondo, T.; Shimizu, T. Protective effects of platinum nanoparticles against UV-light-induced epidermal inflammation. Exp. Dermatol. 2010, 19, 1000-1006. [CrossRef] [PubMed]

22. Hosaka, H.; Haruki, R.; Yamada, K.; Böttcher, C.; Komatsu, T. Hemoglobin-albumin cluster incorporating a Pt nanoparticle: Artificial O2 carrier with antioxidant activities. PLoS ONE 2014, 9, e110541. [CrossRef] [PubMed]

23. Li, S.; Porcel, E.; Remita, H.; Marco, S.; Réfrégiers, M.; Dutertre, M.; Confalonieri, F.; Lacombe, S. Platinum nanoparticles: An exquisite tool to overcome radioresistance. Cancer Nano. 2017, 8, 4. [CrossRef] [PubMed]

24. Pokropivny, V.V.; Skorokhod, V.V. Classification of nanostructures by dimensionality and concept of surface forms engineering in nanomaterial science. Mater. Sci. Eng. C 2007, 27, 990-993. [CrossRef]

25. Tiwari, J.N.; Tiwari, R.N.; Kim, K.S. Zero-dimensional, one-dimensional, two-dimensional and three-dimensional nanostructured materials for advanced electrochemical energy devices. Prog. Mater. Sci. 2012, 57, 724-803. [CrossRef]

26. Tiwari, D.K.; Behari, J.; Sen, P. Application of Nanoparticles in Waste Water Treatment. World J. Appl. Sci. 2008, 3, 417-433.

27. Pease, R.F.; Chou, S.Y. Lithography and Other Patterning Techniques for Future Electronics. Proc. IEEE 2008, 96, 248-270. [CrossRef]

28. Sapsford, K.E.; Tyner, K.M.; Dair, B.J.; Deschamps, J.R.; Medintz, I.L. Analyzing nanomaterial bioconjugates: A review of current and emerging purification and characterization techniques. Anal. Chem. 2011, 83, 4453-4488. [CrossRef]

29. Wang, Y.; Xia, Y. Bottom-up and top-down approaches to the synthesis of monodispersed spherical colloids of low melting-point metals. Nano Lett. 2004, 4, 2047-2050. [CrossRef]

30. Dhand, C.; Dwivedi, N.; Loh, X.J.; Ying, A.; Verma, N.; Beuerman, R.W.; Lakshminarayanan, R.; Ramakrishna, S. Methods and strategies for the synthesis of diverse nanoparticles and their applications: A comprehensive overview. RSC Adv. 2015, 5, 105003-105037. [CrossRef]

31. Nichols, W.T.; Sasaki, T.; Koshizaki, N. Laser ablation of a platinum target in water. III. Laser-induced reactions. J. Appl. Phys. 2006, 100, 114911. [CrossRef]

32. Mafune, F.; Kondow, T. Selective laser fabrication of small nanoparticles and nano-networks in solution by irradiation of UV pulsed laser onto platinum nanoparticles. Chem. Phys. Lett. 2004, 383, 343-347. [CrossRef]

33. Park, D.K.; Lee, S.J.; Lee, J.; Choi, M.Y.; Han, S.W. Effect of polymeric stabilizers on the catalytic activity of Pt nanoparticles synthesized by laser ablation. Chem. Phys. Lett. 2010, 484, 254-257. [CrossRef]

34. Cueto, M.; Sanz, M.; Oujja, M.; Gamez, F.; Haya, M.B.; Castillejo, M. Platinum Nanoparticles Prepared by Laser Ablation in Aqueous Solutions: Fabrication and Application to Laser Desorption Ionization. J. Phys. Chem. C. 2011, 115, 22217-22224. [CrossRef]

35. Maicu, M.; Schmittgens, R.; Hecker, D.; Glob, D.; Frach, P.; Gerlach, G. Synthesis and deposition of metal nanoparticles by gas condensation process. J. Vac. Sci. Technol. A Vac. Surf. Films 2014, 32, 02B113. [CrossRef]

36. Stepanov, A.L.; Golubev, A.N.; Nikitin, S.I.; Osin, Y.N. A Review on the fabrication and properties of platinum nanoparticles. Rev. Adv. Mater. Sci. 2014, 38, 160-175. 
37. Adams, D. Inorganic Solids: An Introduction to Concepts in Solid State Structural Chemistry; John Wiley \& Son: London, UK; New York, NY, USA; Sydney, Australia; Toronto, ON, Canada, 1974.

38. Peng, Z.A.; Peng, X. Formation of high-quality CdTe, CdSe, and CdS nanocrystals using CdO as precursor. J. Am. Chem. Soc. 2001, 123, 183-184. [CrossRef]

39. Qu, L.; Peng, Z.A.; Peng, X. Alternative routes toward high quality CdSe nanocrystals. Nano Lett. 2001, 1, 333-337. [CrossRef]

40. Yamada, M.; Foote, M.; Prow, T.W. Therapeutic gold, silver, and platinum nanoparticles. Wiley Interdiscip. Rev. Nanomed. Nanobiotechnol. 2015, 7, 428-445. [CrossRef]

41. Adlim, M.; Abu Bakar, M.; Liew, K.Y.; Ismail, J. Synthesis of chitosan-stabilized platinum and palladium nanoparticles and their hydrogenation activity. J. Mol. Catal. A Chem. 2004, 212, 141-149. [CrossRef]

42. Kumar, A.; Joshi, H.M.; Mandale, A.B.; Srivastava, R.; Adyanthaya, S.D.; Pasricha, R.; Sastry, M. Phase transfer of platinum nanoparticles from aqueous to organic solutions using fatty amine molecules. J. Chem. Sci. 2004, 116, 293-300. [CrossRef]

43. Shukla, N.; Svedberg, E.B.; Ell, J. Surfactant isomerization and dehydrogenation of FePt nanoparticles. Colloids Surf. A Physicochem. Eng. Asp. 2007, 301, 113-116. [CrossRef]

44. Du, H.Y.; Wang, C.H.; Hsu, H.C.; Chang, S.T.; Chen, U.S.; Yen, S.C.; Chen, L.C.; Shih, H.C.; Chen, K.H. Controlled platinum nanoparticles uniformly dispersed on nitrogen-doped carbon nanotubes for methanol oxidation. Diam. Relat. Mater. 2008, 17, 535-541. [CrossRef]

45. Bonnemann, H.; Richards, R.M. Nanoscopic metal particles-Synthetic methods and potential applications. Eur. J. Inorg. Chem. 2001, 2001, 2455-2480. [CrossRef]

46. Liu, Z.L.; Lee, J.Y.; Han, M.; Chen, W.X.; Gan, L.M. Synthesis and characterization of PtRu/C catalysts from microemulsions and emulsions. J. Mater. Chem. 2002, 12, 2453-2458. [CrossRef]

47. Kyung Tae, K.; Sung-Ho, J.; Seung-Cheol, C.; Deog-Su, P. Green Synthesis of Platinum Nanoparticles by Electroreduction of a $\mathrm{K}_{2} \mathrm{PtCl}_{6}$ Solid-State Precursor and Its Electrocatalytic Effects on $\mathrm{H}_{2} \mathrm{O}_{2}$ Reduction. Bull. Korean Chem. Soc. 2013, 34, 3835-3839.

48. Zeng, J.; Yang, J.L.; Zhou, W. Activities of Pt/C catalysts prepared by low temperature chemical reduction methods. Appl. Catal. A 2006, 308, 99-104. [CrossRef]

49. Meltzer, S.; Resch, R.; Koel, B.; Thompson, M.; Madhukar, A.; Requicha, A. Fabrication of nanostructures by hydroxylamine seeding of gold nanoparticle templates. Langmuir 2001, 17, 1713-1718. [CrossRef]

50. Abdolhosseinzadeh, S.; Sadighikia, S.; Gursel, S.A. Scalable Synthesis of Sub-Nanosized Platinum-Reduced Graphene Oxide Composite by an Ultraprecise Photocatalytic Method. ACS Sustain. Chem. Eng. 2018, 6, 3773-3782. [CrossRef]

51. Reetz, M.T.; Koch, M.G. Water-Soluble Colloidal Adams Catalyst: Preparation and Use in Catalysis. J. Am. Chem. Soc. 1999, 121, 7933-7934. [CrossRef]

52. Du, Y.K.; Yang, P.; Mou, Z.G.; Hua, N.P.; Jiang, L. Thermal decomposition behaviors of PVP coated on platinum nanoparticles. J. Appl. Polym. Sci. 2006, 99, 23-26. [CrossRef]

53. Okitsu, K.; Yue, A.; Tanabe, S.; Matsumoto, H. Sonochemical Preparation and Catalytic Behavior of Highly Dispersed palladium Nanoparticles on Alumina. Chem. Mater. 2000, 12, 3006-3011. [CrossRef]

54. Fujimoto, T.; Terauchi, S.; Umehara, H.; Kojima, I.; Henderson, W. Sonochemical preparation of Single-Dispersion metal nanoparticles from metal salts. Chem. Mater. 2001, 13, 1057-1060. [CrossRef]

55. Saminathan, K.; Kamavaram, V.; Veedu, V.; Kannan, A.M. Preparation and evaluation of electrodeposited platinum nanoparticles on in situ carbon nanotubes grown carbon paper for proton exchange membrane fuel cells. Int. J. Hydrogen Energy 2009, 34, 3838-3844. [CrossRef]

56. Shafiei, M.; Riahi, A.R.; Sen, F.G.; Alpas, A.T. Improvement of platinum adhesion to carbon surfaces using PVD coatings. Surf. Coat. Technol. 2010, 205, 306-311. [CrossRef]

57. Leong, G.J.; Schulze, M.C.; Strand, M.B.; Maloney, D.; Frisco, S.L.; Dinh, H.N.; Pivovar, B.; Richards, R.M. Shape-directed platinum nanoparticle synthesis: Nanoscale design of novel catalysts. Appl. Organomet. Chem. 2014, 28, 1-17. [CrossRef]

58. Tao, A.R.; Habas, S.; Yang, P. Shape Control of Colloidal Metal Nanocrystals. Small 2008, 4, $310-325$. [CrossRef]

59. Chen, J.; Lim, B.; Lee, E.P.; Xia, Y. Shape-controlled synthesis of platinum nanocrystals for catalytic and electrocatalytic applications. Nano Today 2009, 4, 81-95. [CrossRef] 
60. Lim, S.I.; Ojea-Jime’nez, I.; Varon, M.; Casals, E.; Arbiol, J.; Puntes, V. Synthesis of platinum cubes, polypods, cuboctahedrons, and raspberries assisted by cobalt nanocrystals. Nano Lett. 2010, 10, 964-973. [CrossRef]

61. Miyabayashi, K.; Nakamura, S.; Miyake, M. Synthesis of small platinum cube with less than $3 \mathrm{~nm}$ by the control of growth kinetics. Cryst. Growth Des. 2011, 11, 4292-4295. [CrossRef]

62. Gurunathan, S.; Kalishwaralal, K.; Vaidyanathan, R.; Venkataraman, D.; Pandian, S.R.; Muniyandi, J.; Hariharan, N.; Eom, S.H. Biosynthesis, purification and characterization of silver nanoparticles using Escherichia coli. Colloids Surf. B Biointerfaces 2009, 74, 328-335. [CrossRef] [PubMed]

63. Sanchez-Sanchez, C.M.; Solla-Gullon, J.; Vidal-Iglesias, F.J.; Aldaz, A.; Montiel, V.; Herrero, E. Imaging Structure Sensitive Catalysis on Different Shape-Controlled Platinum Nanoparticles. J. Am. Chem. Soc. 2010, 132, 5622-5624. [CrossRef] [PubMed]

64. Formo, E.; Lee, E.; Campbell, D.; Xia, Y.N. Functionalization of Electrospun $\mathrm{TiO}_{2}$ Nanofibers with Pt Nanoparticles and Nanowires for Catalytic Applications. Nano Lett. 2008, 8, 668-672. [CrossRef] [PubMed]

65. Tian, N.; Zhou, Z.Y.; Sun, S.G.; Ding, Y.; Wang, Z.L. Synthesis of tetrahexahedral platinum nanocrystals with high-index facets and high electro-oxidation activity. Science 2007, 316, 732-735. [CrossRef]

66. Mukherjee, P.; Ahmad, A.D.; Mandal, S.; Senapati, S.R.; Sainkar, M.; Khan, I. Bioreduction of AuCl ${ }^{-} \mathrm{Ions}$ by the Fungus, Verticillium sp. and Surface Trapping of the Gold Nanoparticles Formed. Angew. Chem. Int. Ed. 2001, 40, 3585-3588. [CrossRef]

67. Nath, D.; Banerjee, P. Environ Green nanotechnology-A new hope for medical biology. Environ. Toxicol. Pharmacol. 2013, 36, 997-1014. [CrossRef]

68. Kalishwaralal, K.; Deepak, V.; Ramkumarpandian, S.; Nellaiah, H.; Sangiliyandi, G. Extracellular biosynthesis of silver nanoparticles by the culture supernatant of Bacillus licheniformis. Mater. Lett. 2008, 62, 4411-4413. [CrossRef]

69. Kalimuthu, K.; Suresh Babu, R.; Venkataraman, D.; Bilal, M.; Gurunathan, S. Biosynthesis of silver nanocrystals by Bacillus licheniformis. Colloids Surf. B Biointerfaces 2008, 65, 150-153. [CrossRef]

70. Riddin, T.; Gerickeb, M.; Whiteley, C.G. Biological synthesis of platinum nanoparticles: Effect of initial metal concentration. Enzyme Microb. Technol. 2010, 46, 501-505. [CrossRef]

71. Martins, M.; Mourato, C.; Sanches, S.; Noronha, J.P.; Crespo, M.T.B.; Pereira, I.A.C. Biogenic platinum and palladium nanoparticles as new catalysts for the removal of pharmaceutical compounds. Water Res. 2017, 108, 160-168. [CrossRef]

72. Gaidhani, S.V.; Yeshvekar, R.K.; Shedbalkar, U.U.; Bellare, J.H.; Chopade, B.A. Bio-reduction of hexachloroplatinic acid to platinum nanoparticles employing Acinetobacter calcoaceticus. Process. Biochem. 2014, 49, 2313-2319. [CrossRef]

73. Konishi, Y.; Ohno, K.; Saitoh, N.; Nomura, T.; Nagamine, S.; Hishida, H.; Takahashi, Y.; Uruga, T. Bioreductive deposition of platinum nanoparticles on the bacterium Shewanella algae. J. Biotechnol. 2007, 128, 648-653. [CrossRef] [PubMed]

74. Riddin, T.L.; Gericke, M.; Whiteley, C.G. Analysis of the inter-and extracellular formation of platinum nanoparticles by Fusarium oxysporum f. sp. lycopersici using response surface methodology. Nanotechnology 2006, 17, 3482-3489. [CrossRef]

75. Govender, Y.; Riddin, T.; Gericke, M.; Whiteley, C.G. Bioreduction of platinum salts into nanoparticles: A mechanistic perspective. Biotechnol. Lett. 2009, 31, 95-100. [CrossRef]

76. Syed, A.; Ahmad, A. Extracellular biosynthesis of platinum nanoparticles using the fungus Fusarium oxysporum. Colloids Surf. B Biointerfaces 2012, 97, 27-31. [CrossRef]

77. Mohanpuria, P.; Rana, N.K.; Yadav, S.K. Biosynthesis of nanoparticles: Technological concept and future applications. J. Nanopart. Res. 2007, 10, 507-517. [CrossRef]

78. Mukherjee, P.; Roy, M.; Mandal, B.P.; Dey, G.K.; Mukherjee, P.K.; Ghatak, J.; Tyagi, A.K.; Kale, S.P. Green synthesis of highly stabilized nanocrystalline silver particles by a non-pathogenic and agriculturally important fungus T. asperellum. Nanotechnology 2008, 19, 075103. [CrossRef]

79. Narayanan, K.B.; Sakthivel, N. Biological synthesis of metal nanoparticles by microbes. Adv. Colloid Interface Sci. 2010, 156, 1-13. [CrossRef]

80. Castro-Longoria, E.; Moreno-Velasquez, S.D.; Vilchis-Nestor, A.R.; Berumen, E.A.; Borja, M.A. Production of Platinum Nanoparticles and Nanoaggregates Using Neurospora crassa. J. Microbiol. Biotechnol. 2012, 22, 1000-1004. [CrossRef] 
81. Gardea-Torresdey, J.L.; Parsons, J.G.; Gomez, E.; Peralta-Videa, J.; Troiani, H.E.; Santiago, P.; Yacaman, M.J. Formation and Growth of Au Nanoparticles inside live Alfalfa plants. Nano Lett. 2002, 2, 397-401. [CrossRef]

82. Song, J.Y.; Kwon, E.Y.; Kim, B.S. Biological synthesis of platinum nanoparticles using Diopyros kaki leaf extract. Bioprocess. Biosyst. Eng. 2010, 33, 159-164. [CrossRef] [PubMed]

83. Dobrucka, R. Synthesis and structural characteristic of platinum nanoparticles using herbal bidens tripartitus extract. J. Inorg. Organomet. Polym. Mater. 2015, 26, 219-225. [CrossRef]

84. Sheny, D.S.; Philip, D.; Mathew, J. Synthesis of platinum nanoparticles using dried Anacardium occidentale leaf and its catalytic and thermal applications. Spectrochim. Acta A Mol. Biomol. Spectrosc. 2013, 114, 267-271. [CrossRef] [PubMed]

85. Thirumurugan, A.; Aswitha, P.; Kiruthika, C.; Nagarajan, S.; Nancy, C.A. Green synthesis of platinum nanoparticles using Azadirachta indica-An eco-friendly approach. Mater. Lett. 2016, 170, 175-178. [CrossRef]

86. Rajasekharreddy, P.; Rani, P.U. Biosynthesis and characterization of Pd and Pt nanoparticles using Piper betle L. plant in a photoreduction method. J. Cluster Sci. 2014, 25, 1377-1388. [CrossRef]

87. Soundarrajan, C.; Sankari, A.; Dhandapani, P.; Maruthamuthu, S.; Ravichandran, S.; Sozhan, G.; Palaniswamy, N. Rapid biological synthesis of platinum nanoparticles using Ocimum sanctum for water electrolysis applications. Bioprocess. Biosyst. Eng. 2012, 35, 827-833. [CrossRef]

88. Huang, J.; Li, Q.; Sun, D.; Lu, Y.; Su, Y.; Yang, X.; Wang, H.; Wang, Y.; Shao, W.; He, N.; et al. Biosynthesis of silver and gold nanoparticles by novel sundried Cinnamomum camphora leaf. Nanotechnology 2007, 18, 105104-105114. [CrossRef]

89. Gopi, K.J.R.; Panneerselvam, R. Quantification of colchicine in seed and tuber samples of Gloriosa superba by high performance liquid chromatography method. J. Appl. Pharm. Sci. 2011, 1, 116-119.

90. Coccia, F.; Tonucci, L.; Bosco, D.; Bressan, M.; Alessandro, N.D. One pot synthesis of lignin-stabilized platinum and palladium nanoparticles and their catalytic behaviours in oxidation and reduction reactions. Green Chem. 2012, 14, 1073-1078. [CrossRef]

91. Al-Radadi, N.S. Green synthesis of platinum nanoparticles using Saudi's Dates extract and their usage on the cancer cell treatment. Arab. J. Chem. 2019, 12, 330-349. [CrossRef]

92. Xiaobo, L.; Min, W.; Dayong, W.; Shigenori, K.; Takashi, E.; Yong, H. Platinum nanoparticles using wood nanomaterials: Green synthesis, shape control and catalytic activity for p-nitrophenol reduction. Green Chem. 2011, 13, 283.

93. Musthafa, O.M.; Sudip, C.; Tasneem, A.; Shahid, A.A.A. Clean-Green Synthesis of Platinum Nanoparticles Utilizing a Pernicious Weed Lantana (Lantana camara). Am. J. Eng. Appl. Sci. 2016, 9, 84-90.

94. Velmurugan, P.; Shim, J.; Kim, K.; Oh, B.T. Prunus $\times$ yedoensis tree gum mediated synthesis of platinum nanoparticles with antifungal activity against phytopathogens. Mater. Lett. 2016, 174, 61-65. [CrossRef]

95. Alshatwi, A.A.; Athinarayanan, J.; Subbarayan, P.V. Green synthesis of platinum nanoparticles that induce cell death and G2/M-phase cell cycle arrest in human cervical cancer cells. J. Mater. Sci. Mater. Med. 2015, 26, 1-9. [CrossRef] [PubMed]

96. Ganaie, S.U.; Abbasi, T.; Abbasi, S.A. Biomimetic synthesis of platinum nanoparticles utilizing a terrestrial weed Antigonon leptopu. Part. Sci. Technol. 2017, 36, 681-688. [CrossRef]

97. Rokade, S.; Joshi, K.A.; Mahajan, K.; Tomar, G.; Dubal, D.S.; Parihar, V.S.; Kitture, R.; Bellare, J.; Ghosh, S. Novel Anticancer Platinum and Palladium Nanoparticles from Barleria prionitis. Glob. J. Nanomed. 2017, 2, 555-600.

98. Dauthal, P.; Mukhopadhyay, M. Biofabrication, characterization, and possible bio-reduction mechanism of platinum nanoparticles mediated by agro-industrial waste and their catalytic activity. J. Ind. Eng. Chem. 2015, 22, 185-191. [CrossRef]

99. Marslin, G.; Siram, K.; Maqbool, Q.; Selvakesavan, R.K.; Kruszka, D.; Kachlicki, P.; Franklin, G. Secondary Metabolites in the Green Synthesis of Metallic Nanoparticles. Materials 2018, 11, 940. [CrossRef]

100. Sahin, B.; Aygün, A.; Gündüz, H.; Sahin, K.; Demir, E.; Akocak, S.; Sen, F. Cytotoxic Effects of Platinum Nanoparticles Obtained from Pomegranate Extract by the Green Synthesis Method on the MCF-7 Cell Line. Colloids Surf. B Biointerfaces 2018, 163, 119-124. [CrossRef]

101. Gurunathan, S.; Jeyaraj, M.; Kang, M.-H.; Kim, J.-H. The Effects of Apigenin-Biosynthesized Ultra-Small Platinum Nanoparticles on the Human Monocytic THP-1 Cell Line. Cells 2019, 8, 444. [CrossRef] 
102. Gurunathan, S.; Kang, M.-H.; Jeyaraj, M.; Kim, J.-H. Differential immunomodulatory effect of graphene oxide and vanillin-functionalized graphene oxide nanoparticles in human acute monocytic leukemia cell line (THP-1). Int. J. Mol. Sci. 2019, 20, 247. [CrossRef] [PubMed]

103. Tomaszewska, E.; Soliwoda, K.; Kadziola, K.; Celichowski, G.; Cichomski, M.; Szmaja, W.; Grobelny, J. Detection limits of DLS and UV-Vis spectroscopy in characterization of polydisperse nanoparticles colloids. J. Nanomater. 2013, 2013, 60. [CrossRef]

104. Cao, G. Nanostructures and Nanomaterials. Synthesis, Properties, and Applications; Imperial College Press: London, UK, 2004. [CrossRef]

105. Gurunathan, S.; Han, J.W.; Kwon, D.N.; Kim, J.-H. Enhanced antibacterial and anti-biofilm activities of silver nanoparticles against Gram-negative and Gram-positive bacteria. Nanoscale. Res. Lett. 2014, 9, 373. [CrossRef] [PubMed]

106. Lin, P.C.; Lin, S.; Wang, P.C.; Sridhar, R. Techniques for physicochemical characterization of nanomaterials. Biotechnol. Adv. 2014, 32, 711-726. [CrossRef] [PubMed]

107. Shang, L.; Wang, Y.; Jiang, J.; Dong, S. pH-dependent protein conformational changes in albumin: Gold nanoparticle bioconjugates: A spectroscopic study. Langmuir 2007, 23, 2714-2721. [CrossRef]

108. Perevedentseva, E.V.; Su, F.Y.; Su, T.H.; Lin, Y.C.; Cheng, C.L.; Karmenyan, A.V.; Priezzhev, A.V.; Lugovtsov, A.E. Laser-optical investigation of the effect of diamond nanoparticles on the structure and functional properties of proteins. Quantum Electron. 2010, 40, 1089-1093. [CrossRef]

109. Charles, B.; Cher, M.T.; Jeng, C.K. FTIR spectroscopy as a tool for nano-material characterization. Inf. Biophys. Technol. 2010, 53, 434-438.

110. Dzakpasu, R.; Axelrod, D. Dynamic light scattering microscopy. A novel optical technique to image submicroscopic motions. I: Theory. Biophys. J. 2004, 87, 1279-1287. [CrossRef]

111. Digman, M.A.; Gratton, E. Lessons in fluctuation correlation spectroscopy. Annu. Rev. Phys. Chem. 2011, 62, 645-668. [CrossRef]

112. Satoh, A.; Chantrell, R.W.; Brownian, G.N. Dynamics Simulations of Ferromagnetic Colloidal Dispersions in a Simple Shear Flow Coverdale. J. Colloid Interface Sci. 1999, 209, 44-59. [CrossRef]

113. Brar, S.K.; Verma, M. Measurement of nanoparticle by light scattering techniques. TrAC Trends Anal. Chem. 2011, 30, 4-17. [CrossRef]

114. Stetefeld, J.; McKenna, S.A.; Patel, T.R. Dynamic light scattering: A practical guide and applications in biomedical sciences. Biophy. Rev. 2016, 8, 409-427. [CrossRef] [PubMed]

115. Cantor, C.R.; Schimmel, P.R.; Freeman Ed, W.H. Techniques for the Study of Biological Structure and Function; Standford Libraries, Standford Publishers: San Francisco, CA, USA, 1980.

116. Waseda, Y.; Matsubara, E.; Shinoda, K.; Springer, V. X-Ray Diffraction Crystallography; Springer: Berlin, Germany, 2011.

117. Strasser, P.; Koh, S.; Anniyev, T.; Greeley, J.; More, K.; Yu, C.; Liu, Z.; Kaya, S.; Nordlund, D.; Ogasawara, H.; et al. Lattice-strain control of the activity in dealloyed core-shell fuel cell catalysts. Nat. Chem. 2010, 2, 454-460. [CrossRef] [PubMed]

118. Aguirre, F.M.A.; Bazán-Díaz, L.; Mendoza-Cruz, R.; Gómez-Rodríguez, A.; Zorrilla-Cangas, C.; Herrera-Becerra, R. Nano Phase Characterization by Transmission Electron Microscopy: Experimental and Simulation. Mater. Sci. Appl. 2015, 6, 935. [CrossRef]

119. Goldstein, J.I.; Newbury, D.E.; Echlin, P.; Joy, D.C.; Lyman, C.E.; Lifshin, E.; Sawyer, L.; Michael, J.R. Scanning Electron. Microscopy and X-Ray Microanalysis, 3rd ed.; Kluwer Academic/Plenum Publishers: New York, NY, USA, 2003.

120. Bogner, A.; Jouneau, P.-H.; Thollet, G.; Basset, D.; Gauthier, C. A history of scanning electron microscopy developments: Towards "wet-STEM" imaging. Micron 2007, 38, 390-401. [CrossRef] [PubMed]

121. Hawkes, P.W. The correction of electron lens aberrations. Ultramicroscopy 2015, 156, A1-A64. [CrossRef]

122. Takenaka, S.; Karg, E.; Kreyling, W.G.; Lentner, B.; Möller, W.; BehnkeSemmler, M.; Jennen, L.; Walch, A.; Michalke, B.; Schramel, P.; et al. Distribution pattern of inhaled ultrafine gold particles in the rat lung. Inhal. Toxicol. 2006, 18, 733-740. [CrossRef]

123. Beck-Speier, I.; Dayal, N.; Karg, E.; Maier, K.L.; Schumann, G.; Schulz, H.; Semmler, M.; Takenaka, S.; Stettmaier, K.; Bors, W.; et al. Oxidative stress and lipid mediators induced in alveolar macrophages by ultrafine particles. Free Radic. Biol, Med. 2005, 38, 1080-1092. [CrossRef] 
124. Stearns, R.C.; Paulauskis, J.D.; Godleski, J.J. Endocytosis of ultrafine particles by A549 cells. Am. J. Respir. Cell Mol. Biol. 2001, 24, 108-115. [CrossRef]

125. Pulskamp, K.; Diabaté, S.; Krug, H. Carbon nanotubes show no sign of acute toxicity but induce intracellular reactive oxygen species in dependence on contaminants. Toxicol. Lett. 2007, 168, 58-74. [CrossRef]

126. Worcester, D.L.; Miller, R.G.; Bryant, P.J. Atomic force microscopy of purple membranes. J. Microsc. 1988, 152, 817-821. [CrossRef] [PubMed]

127. Bustamante, C.; Vesenka, J.; Tang, C.L.; Rees, W.; Guthod, M.; Keller, R. Circular DNA molecules imaged in air by scanning force microscopy. Biochemistry 1992, 31, 22-26. [CrossRef] [PubMed]

128. Wiesendanger, R. Scanning Probe Microscopy and Spectroscopy; Cambridge University Press: Cambridge, UK, 1994; p. 659. ISBN 0521418100.

129. Pelling, A.E.; Sehati, S.; Gralla, E.B.; Valentine, J.S.; Gimzewski, J.K. Local nanomechanical motion of the cell wall of Saccharomyces cerevisiae. Science 2004, 305, 1147-1150. [CrossRef]

130. Horber, J.K.; Miles, M.J. Scanning probe evolution in biology. Science 2003, 302, 1002-1005. [CrossRef]

131. Charras, G.T.; Horton, M.A. Single cell mechanotransduction and its modulation analyzed by atomic force microscope indentation. Biophys. J. 2002, 82, 2970-2981. [CrossRef]

132. Greenleaf, W.J.; Woodside, M.T.; Block, S.M. High-resolution, single-molecule measurements of biomolecular motion. Annu. Rev. Biophys. Biomol. Struct. 2007, 36, 171-190. [CrossRef]

133. Dufrêne, Y.F. Using nanotechniques to explore microbial surfaces. Nat. Rev. Microbiol. 2004, 2, 2,451-460. [CrossRef]

134. Rabinovich, Y.; Esayanur, M.; Daosukho, S.; Byer, K.; El-Shall, H.; Khan, S. Atomic force microscopy measurement of the elastic properties of the kidney epithelial cells. J. Colloid Interface Sci. 2005, 285, 125-135. [CrossRef]

135. Osada, T.; Uehara, H.; Kim, H.; Ikai, A. Clinical laboratory implications of single living cell mRNA analysis. Adv. Clin. Chem. 2004, 38, 239-257.

136. Uehara, H.; Osada, T.; Ikai, A. Quantitative measurement of mRNA at different loci within an individual living cell. Ultramicroscopy 2004, 100, 197-201. [CrossRef]

137. Uehara, H.; Ikai, A.; Osada, T. Detection of mRNA in single living cells using AFM nanoprobes. Micro Nano Technol. Bioanal. 2009, 544, 599-608.

138. Hu, M.; Wang, J.; Zhao, H.; Dong, S.; Cai, J. Nanostructure and nanomechanics analysis of lymphocyte using AFM: From resting, activated to apoptosis. J. Biomech. 2009, 42, 1513-1519. [CrossRef] [PubMed]

139. Fotiadis, D.; Scheuring, S.; Müller, S.A.; Engel, A.; Müller, D.J. Imaging and manipulation of biological structures with the AFM. Micron 2002, 33, 385-397. [CrossRef]

140. Vlaic, G.; Olivi, L. EXAFS Spectroscopy: A Brief Introduction. Croat. Chem. Acta 2004, 77, 427-433.

141. Kossel, W. Rontgenspektren. Z. Phys. 1920, 1, 119. [CrossRef]

142. Kim, D.K.; Kan, D.; Veres, T.; Normadin, F.; Liao, J.K.; Kim, H.H.; Lee, S.-H.; Zahn, M.; Muhammed, M. Monodispersed Fe-Pt nanoparticles for biomedical applications. J. Appl. Phys. 2005, 97, 10-18. [CrossRef]

143. Sun, S. Recent Advances in Chemical Synthesis, Self-Assembly, and Applications of FePt Nanoparticles. Adv. Mater. 2006, 18, 393-403. [CrossRef]

144. Chiang, P.C.; Hung, D.S.; Wang, J.W.; Ho, C.S.; Yao, Y.D. Engineering Water-Dispersible FePt Nanoparticles for Biomedical Applications. IEEE Trans. Magn. 2007, 43, 2445. [CrossRef]

145. Shi, Y.; Lin, M.; Jiang, X.; Liang, S. Recent Advances in FePt Nanoparticles for Biomedicine. J. Nanomater. 2015, 2015, 13. [CrossRef]

146. Maenosono, S.; Saita, S. Theoretical Assessment of FePt Nanoparticles as Heating Elements for Magnetic Hyperthermia. IEEE Trans. Magn. 2006, 42, 1638. [CrossRef]

147. Seehra, M.S.; Singh, V.; Dutta, P.; Neeleshwar, S.; Chen, Y.Y.; Chen, C.L.; Chou, S.W.; Chen, C.C. Size-dependent magnetic parameters of fcc FePt nanoparticles: Applications to magnetic hyperthermia. J. Phys. D Appl. Phys. 2010, 43, 145002. [CrossRef]

148. Maenosono, S.; Suzuki, T.; Saita, S. Superparamagnetic FePt nanoparticles as excellent MRI contrast agents. J. Magn. Magn. Mater. 2008, 320, L79-L83. [CrossRef]

149. Taylor, R.M.; Sillerud, L.O. Paclitaxel-loaded iron platinum stealth immunomicelles are potent MRI imaging agents that prevent prostate cancer growth in a PSMA-dependent manner. Int. J. Nanomed. 2012, 7, 4341-4352. [CrossRef] 
150. Yang, H.; Zhang, J.; Tian, Q. One-pot synthesis of amphiphilic superparamagnetic FePt nanoparticles and magnetic resonance imaging in vitro. J. Magn. Magn. Mater. 2010, 322, 973-977. [CrossRef]

151. Chou, S.W.; Shau, Y.H.; Wu, P.C.; Yang, Y.S.; Shieh, D.B.; Chen, C.C. In Vitro and in Vivo Studies of FePt Nanoparticles for Dual Modal CT/MRI Molecular Imaging. J. Am. Chem. Soc. 2010, 13238, 13270-13278. [CrossRef]

152. Lai, S.M.; Tsai, T.Y.; Hsu, C.Y.; Tsai, J.L.; Liao, M.Y.; Lai, P.S. Bifunctional silica-coated superparamagnetic FePt nanoparticles for fluorescence/MR dual imaging. J. Nanomater. 2012, 2012, 631584. [CrossRef]

153. Liang, S.; Zhou, Q.; Wang, M.; Zhu, Y.; Wu, Q.; Yang, X. Water-soluble l-cysteine-coated FePt nanoparticles as dual MRI/CT imaging contrast agent for glioma. Int. J. Nanomed. 2015, 10, 2325-2333.

154. Fuchigami, T.; Kawamura, R.; Kitamoto, Y.; Nakagawa, M.; Namiki, Y. A magnetically guided anti-cancer drug delivery system using porous FePt capsules. Biomaterials 2012, 33, 1682-1687. [CrossRef]

155. Chen, C.-L.; Kuo, L.-R.; Lee, S.-Y. Photothermal cancer therapy via femtosecond-laser-excited FePt nanoparticles. Biomaterials 2013, 34, 1128-1134. [CrossRef]

156. Sun, H.; Xu, L.; Fan, T.; Zhan, H.; Wang, X.; Zhou, Y.; Yang, R. Targeted hyperthermia after selective embolization with ferromagnetic nanoparticles in a $\mathrm{VX}_{2}$ rabbit liver tumor model. Int. J..Nanomed. 2013, 8, 3795-3804. [CrossRef]

157. Seemann, K.M.; Luysberg, M.; Révay, Z. Magnetic heating properties and neutron activation of tungsten-oxide coated biocompatible FePt core-shell nanoparticles. J. Control. Release 2015, 197, 131-137. [CrossRef] [PubMed]

158. Zheng, Y.; Tang, Y.; Bao, Z.; Wang, H.; Ren, F.; Guo, M.; Quan, H.; Jiang, C. FePt nanoparticles as a potential X-ray activated chemotherapy agent for HeLa cells. Int. J. Nanomed. 2015, 10, 64356-66444. [CrossRef] [PubMed]

159. Moghimi, N.; Leung, K.T. FePt alloy nanoparticles for biosensing: Enhancement of vitamin C sensor performance and selectivity by nanoalloying. Anal. Chem. 2013, 85, 5974-5980. [CrossRef]

160. Beyth, N.; Houri-Haddad, Y.; Domb, A.; Khan, W.; Hazan, R. Alternative antimicrobial approach: Nano-antimicrobial materials. Evid. Based Complement. Altern. Med. 2015. [CrossRef] [PubMed]

161. Chwalibog, A.; Sawosz, E.; Hotowy, A.; Szeliga, J.; Mitura, S.; Mitura, K.; Grodzik, M.; Orlowski, P.; Sokolowska, A. Visualization of interaction between inorganic nanoparticles and bacteria or fungi. Int. J. Nanomed. 2010, 5, 1085-1094. [CrossRef]

162. Rosenberg, B.; Vancamp, L.; Krigas, T. Inhibition of cell division in Escherichia coli by electrolysis products from a platinum electrode. Nature 1965, 205, 698-699. [CrossRef]

163. Ma, S.; Izutani, N.; Imazato, S.; Chen, J.; Kiba, W.; Yoshikawa, R.; Takeda, K.; Kitagawa, H.; Ebisu, S. Assessment of bactericidal effects of quaternary ammonium-based antibacterial monomers in combination with colloidal platinum nanoparticles. Dent. Mater. J. 2012, 31, 150-156. [CrossRef]

164. Boomi, P.; Prabu, H.G.; Mathiyarasu, J. Synthesis and characterization of polyaniline/Ag-Pt nanocomposite for improved antibacterial activity. Colloids Surf. B 2013, 103, 9-14. [CrossRef]

165. Elhusseiny, A.F.; Hassan, H.H. Antimicrobial and antitumor activity of platinum and palladium complexes of novel spherical aramides nanoparticles containing flexibilizing linkages: Structure-property relationship. Spectrochim. Acta Part. A Mol. Biomol. Spectrosc. 2013, 103, 232-245. [CrossRef]

166. Zhao, Y.; Ye, C.; Liu, W.; Chen, R.; Jiang, X. Tuning the Composition of AuPt Bimetallic Nanoparticles for Antibacterial Application. Angew. Chem. 2014, 126, 8265-8269. [CrossRef]

167. Judy, G.; Nazim, H.; Manikandan, M.; Hui-Fen, W. Bacterial toxicity/compatibility of platinum nanospheres, nanocuboids and nanoflowers. Sci. Rep. 2013, 3, 1260.

168. Taglietti, A.; Diaz Fernandez, Y.A.; Amato, E.; Cucca, L.; Dacarro, G.; Grisoli, P.; Necchi, V.; Pallavicini, P.; Pasotti, L.; Patrini, M. Antibacterial activity of glutathione-coated silver nanoparticles against Gram positive and Gram negative bacteria. Langmuir 2012, 28, 8140-8148. [CrossRef] [PubMed]

169. Ahmed, K.B.A.; Raman, T.; Anbazhagan, V. Platinum nanoparticles inhibit bacteria proliferation and rescue zebrafish from bacterial infection. RSC Adv. 2016, 6, 44415. [CrossRef]

170. Boomi, P.; Gurumallesh Prabu, H.; Mathiyarasu, J. Synthesis, characterization and antibacterial activity of polyaniline/Pt-Pd nanocomposite. Eur. J. Med. Chem. 2014, 72, 18-25. [CrossRef]

171. Nam, K.Y. Characterization and bacterial anti-adherent effect on modified PMMA denture acrylic resin containing platinum nanoparticles. J. Adv. Prosthodont. 2014, 3, 207-214. [CrossRef] 
172. Ramkumar, V.S.; Pugazhendhi, A.; Prakash, S.; Ahila, N.K.; Vinoj, G.; Selvam, S.; Kumar, G.; Kannapiran, E.; Babu Rajendran, R. Synthesis of platinum nanoparticles using seaweed Padina gymnospora and their catalytic activity as PVP/PtNPs nanocomposite towards biological applications. Biomed. Pharmacother. 2017, 92, 479-490. [CrossRef]

173. Deepika, G.; Sashidhar, R.B. Biopolymer-mediated synthesis and characterization of platinum nanocomposite and its anti-fungal activity against A. parasiticus and A. flavus. Micro Nano Lett. 2018, 13, 1491-1496.

174. Lucky, S.S.; Soo, K.C.; Zhang, Y. Nanoparticles in Photodynamic Therapy. Chem. Rev. 2015, 115, 1990-2042. [CrossRef]

175. Rosenberg, B.; Vancamp, L.; Trosko, J.E.; Mansour, V.H. Platinum compounds: A new class of potent antitumour agents. Nature 1969, 222, 385-386. [CrossRef]

176. Galanski, M.; Jakupec, M.A.; Keppler, B.K. Update of the preclinical situation of anticancer platinum complexes: Novel design strategies and innovative analytical approaches. Curr. Med. Chem. 2005, 12, 2075-2094. [CrossRef]

177. Kelloff, G.J. Perspectives on cancer chemoprevention research and drug development. Adv. Cancer Res. 2000, 78, 199-334. [PubMed]

178. Goodsell, D.S. The molecular perspective: Cisplatin. Stem Cells 2006, 24, 514-515. [CrossRef] [PubMed]

179. Wheate, N.J.; Walker, S.; Craig, G.E.; Oun, R. The status of platinum anticancer drugs in the clinic and in clinical trials. Dalton Trans. 2010, 39, 8113-8127. [CrossRef] [PubMed]

180. Howlader, N. SEER Cancer Statistics Review, 1975-2009; National Cancer Institute: Bethesda, MD, USA, 2012.

181. Pelka, J.; Gehrke, H.; Esselen, M.; Turk, M.; Crone, M.; Brase, S.; Muller, T.; Blank, H.; Send, W.; Zibat, V.; et al. Cellular uptake of platinum nanoparticles in human colon carcinoma cells and their impact on cellular redox systems and DNA integrity. Chem. Res. Toxicol. 2009, 22, 649-659. [CrossRef]

182. Cemazar, M.; Milacic, R.; Miklavcic, D.; Dolzan, V.; Sersa, G. Intratumoral cisplatin administration in electro chemotherapy: Antitumor effectiveness, sequence dependence and platinum content. Anticancer Drugs 1998, 9, 525-530. [CrossRef]

183. Getaz, E.P.; Beckley, S.; Fitzpatrick, J.; Dozier, A. Cisplatin Induced Hemolysis. N. Engl. J. Med. 1980, 302, 334-335. [CrossRef]

184. Kim, Y.S.; Kim, J.S.; Cho, H.S.; Rha, D.S.; Kim, J.M.; Park, J.D.; Choi, B.S.; Lim, R.; Chang, H.K.; Chung, Y.H.; et al. Twenty-eight-day oral toxicity, genotoxicity, and gender-related tissue distribution of silver nanoparticles in Sprague-Dawley rats. J. Inhal. Toxicol. 2008, 9, 575-583. [CrossRef]

185. Wang, D.; Lippard, S.J. Cellular processing of platinum anticancer drugs. Nat. Rev. Drug Discov. 2005, 4, 307-320. [CrossRef]

186. Comenge, J.; Sotelo, C.; Romero, F.; Gallego, O.; Barnadas, A.; Parada, T.G.C.; Domínguez, F.; Puntes, V.F. Detoxifying Antitumoral Drugs via Nanoconjugation: The Case of Gold Nanoparticles and Cisplatin. PLoS ONE 2012, 7, e47562. [CrossRef]

187. Rousseau, J.; Barth, R.F.; Fernandez, M.; Adam, J.F.; Balosso, J.; Estève, F.; Elleaume, H. Efficacy of intracerebral delivery of cisplatin in combination with photon irradiation for treatment of brain tumors. J. Neuro Oncol. 2010, 8, 287-295. [CrossRef]

188. Silici, S.; Ekmekcioglu, O.; Kanbur, M.; Deniz, K. The protective effect of royal jelly against cisplatin-induced renal oxidative stress in rats. World J. Urol. 2011, 8, 127-132. [CrossRef] [PubMed]

189. Wakai, S.; Hirokawa, N. Development of the blood-brain barrier to horseradish peroxidase in the chick embryo. Cell Tissue Res. 1978, 8, 195-203. [CrossRef] [PubMed]

190. Shen, D.W.; Pouliot, L.M.; Hall, M.D.; Gottesman, M.M. Cisplatin resistance: A cellular self-defense mechanism resulting from multiple epigenetic and genetic changes. Pharmacol. Rev. 2012, 8, 706-721. [CrossRef] [PubMed]

191. Prasek, M.; Sawosz, E.; Jaworski, S.; Grodzik, M.; Ostaszewska, T.; Kamaszewski, M.; Wierzbicki, M.; Chwalibog, A. Influence of nanoparticles of platinum on chicken embryo development and brain morphology. Nanoscale Res. Lett. 2013, 8, 1-9. [CrossRef]

192. Sutradhar, K.B.; Amin, M.L. Nanotechnology in Cancer Drug Delivery and Selective Targeting. Nanotechnology 2014. [CrossRef]

193. Borse, V.; Kaler, A.; Banerjee, U.C. Microbial synthesis of platinum nanoparticles and evaluation of their anticancer activity. Int. J. Emerg. Trends Electr. Electron. 2015, 11, 26-31. 
194. Ghosh, S.; Nitnavare, R.; Dewle, A.; Tomar, G.B.; Chippalkatti, R.; More, P.; Kitture, R.; Kale, S.; Bellare, J.; Chopad, B.A. Novel platinum-palladium bimetallic nanoparticles synthesized by Dioscorea bulbifera: Anticancer and antioxidant activities. Int. J. Nanomed. 2015, 10, 7477-7490.

195. Bendale, Y.; Bendale, V.; Natu, R.; Paul, S. Biosynthesized Platinum Nanoparticles Inhibit the Proliferation of Human Lung-Cancer Cells in vitro and Delay the Growth of a Human Lung-Tumor Xenograft in vivo-In vitro and in vivo Anticancer Activity of bio-Pt NPs. J. Pharmacopunct. 2016, 19, 114-121.

196. Medhat, A.; Mansour, S.; El-sonbaty, S.; Kandil, E.; Mahmoud, M. Evaluation of the antitumor activity of platinum nanoparticles in the treatment of hepatocellular carcinoma induced in rats. Tumor Biol. 2017, 39. [CrossRef]

197. Kutwin, M.; Sawosz, E.; Jaworski, S.; Hinzmann, M.; Wierzbicki, M.; Hotowy, A.; Grodzik, M.; Winnicka, A.; Chwalibog, A. Investigation of platinum nanoparticle properties against U87 glioblastoma multiforme. Arch. Med. Sci. 2017, 6, 1322-1334. [CrossRef]

198. Gurunathan, S.; Jeyaraj, M.; Kang, M.-H.; Kim, J.-H. Graphene Oxide_Platinum Nanoparticle Nanocomposites: A Suitable Biocompatible Therapeutic Agent for Prostate Cancer. Polymers 2019, 11, 733. [CrossRef] [PubMed]

199. Saha, K.; Agasti, S.S.; Kim, C.; Li, X.; Rotello, V.M. Gold nanoparticles in chemical and biological sensing. Chem. Rev. 2012, 112, 2739-2779. [CrossRef] [PubMed]

200. Thakor, A.S.; Jokerst, J.; Zavaleta, C.; Massoud, T.F.; Gambhir, S.S. Gold nanoparticles:A Revival in precious Metal Administration to Patients. Nano Lett. 2011, 11, 4029-4036. [CrossRef] [PubMed]

201. Brook, M.A. Platinum in silicone breast implants. Biomaterials 2006, 27, 3274-3286. [CrossRef]

202. Ghosh, P.; Han, G.; De, M.; Kim, C.K.; Rotello, V.M. Gold nanoparticles in delivery applications. Adv. Drug Deliv. Rev. 2008, 60, 1307-1315. [CrossRef]

203. Manikandan, M.; Hasan, N.; Wu, H.F. Platinum nanoparticles for the photothermal treatment of Neuro $2 \mathrm{~A}$ cancer cells. Biomaterials 2013, 34, 5833-5842. [CrossRef]

204. Porcel, E.; Liehn, S.; Remita, H.; Usami, N.; Koayashi, K.; Furusawa, Y.; Lesech, C.; Lacombe, S. Platinum nanoparticles: A promising material for future cancer therapy? Nanotechnology 2010, 21, 085103. [CrossRef]

205. Shvedova, A.; Pietroiusti, A.; Kagan, V. Nanotoxicology ten years later: Lights and shadows. Toxicol. Appl. Pharmacol. 2016, 299, 1-2. [CrossRef]

206. Sukhanova, A.; Bozrova, S.; Sokolov, P.; Berestovoy, M.; Karaulov, A.; Sukhanova, I.N. Dependence of Nanoparticle Toxicity on Their Physical and Chemical Properties. Nanoscale Res. Lett. 2018, 13, 44. [CrossRef]

207. Elder, A.; Yang, H.; Gwiazda, R.; Teng, X.; Thurston, S.; He, H.; Oberdorster, G. Testing Nanomaterials of Unknown Toxicity: An Example Based on Platinum Nanoparticles of Different Shapes. Adv. Mater. 2007, 19, 3124-3129. [CrossRef]

208. Kostova, I. Platinum complexes as anticancer agents. Recent Pat. Anticancer Drug Discov. 2006, 1, 1-22. [CrossRef] [PubMed]

209. Onizawa, S.; Aoshiba, K.; Kajita, M.; Miyamoto, Y.; Nagai, A. Platinum nanoparticle antioxidants inhibit pulmonary inflammation in mice exposed to cigarette smoke. Pulm. Pharmacol. 2009, 22, 340-349. [CrossRef] [PubMed]

210. Gao, J.; Liang, G.; Zhang, B.; Kuang, Y.; Zhang, X.; Xu, B. FePt@CoS(2) yolk-shell nanocrystals as a potent agent to kill HeLa cells. J. Am. Chem. Soc. 2007, 129, 1428-1433. [CrossRef] [PubMed]

211. Teow, Y.; Valiyaveettil, S. Active targeting of cancer cells using folic acid-conjugated platinum nanoparticles. Nanoscale 2010, 2, 2607-2613. [CrossRef]

212. Asharani, P.V.; Xinyi, N.; Hande, M.P.; Valiyaveettil, S. DNA damage and p53-mediated growth arrest in human cells treated with PtNPs. Nanomedicine 2010, 5, 51-64. [CrossRef]

213. Konieczny, P.; Anna, G.G.; Skalniak, L.; Koziel, J.; Francesca, L.F.; Crosera, M.; Cierniak, A.; Zuba, S.; Borowczyk, J.; Laczna, E.; et al. Effects triggered by platinum nanoparticles on primary keratinocytes. Int. J. Nanomed. 2013, 8, 3963-3975.

214. Hashimoto, M.; Kawai, K.; Kawakami, H.; Imazato, S. Matrix metalloproteases inhibition and biocompatibility of gold and platinum nanoparticles. J. Biomed. Mater. Res. Part. A 2016, 104, 209-217. [CrossRef]

215. Subramaniyan, S.B.; Ramani, A.; Ganapathi, V.; Anbazhan, V. Preparation of self-assembled platinum nanoclusters to combat Salmonella typhi infection and inhibit biofilm formation. Colloids Surf. B Biointerfaces 2018, 171, 75-84. [CrossRef]

216. Loan, T.T.; Do, L.T.; Yoo, H. Platinum Nanoparticles Induce Apoptosis on Raw 264.7 Macrophage Cells. J. Nanosci. Nanotechnol. 2018, 18, 861-864. [CrossRef] 
217. Wei, Z.; Yin, X.; Cai, Y.; Xu, W.; Song, C.; Wang, Y.; Zhang, J.; Kang, A.; Wang, Z.; Wei, H. Antitumor effect of a Pt-loaded nanocomposite based on graphene quantum dots combats hypoxia-induced chemoresistance of oral squamous cell carcinoma. Int. J. Nanomed. 2018, 13, 1505-1524. [CrossRef]

218. Almeer, R.S.; Ali, D.; Alarifi, S.; Alkahtani, S.; Almansour, M. Green Platinum Nanoparticles Interaction With HEK293 Cells: Cellular Toxicity, Apoptosis, and Genetic Damage. Dose Response 2018, 16, 1559325818807382. [CrossRef] [PubMed]

219. Shoshan, M.S.; Vonderach, T.; Hattendorf, B.; Wennemers, H. Peptide-Coated Platinum Nanoparticles with Selective Toxicity against Liver Cancer Cells. Angew. Chem. 2019, 58, 4901-4905. [CrossRef] [PubMed]

220. Tanaka, M.; Okinaga, T.; Iwanaga, K.; Matsuo, K.; Toyono, T.; Sasaguri, M.; Ariyoshi, W.; Tominaga, K.; Enomoto, Y.; Matsumura, Y.; et al. Anticancer effect of novel platinum nanocomposite beads on oral squamous cell carcinoma cells. J. Biomed. Mater. Res. Part. B 2019, 107, 2281-2287. [CrossRef] [PubMed]

221. Asharani, P.V.; Lianwu, Y.; Gong, Z.; Valiyaveettil, S. Comparison of the toxicity of silver, gold and PtNPs in developing zebrafish embryos. Nanotoxicology 2011, 5, 43-54. [CrossRef]

222. Labrador-Rached, C.J.; Browning, R.T.; Braydich-Stolle, L.K.; Comfort, K.K. Toxicological Implications of Platinum Nanoparticle Exposure: Stimulation of Intracellular Stress, Inflammatory Response, and Akt Signaling In Vitro. J. Toxicol. 2018, 136, 7801. [CrossRef]

223. Gehrke, H.; Pelka, J.; Hartinger, C.G.; Blank, H.; Bleimund, F.; Schneider, R.; Gerthsen, D.; Brase, S.; Crone, M.; Turk, M.; et al. Platinum nanoparticles and their cellular uptake and DNA platination at non-cytotoxic concentrations. Arch. Toxicol. 2011, 85, 799-812. [CrossRef]

224. Mironava, T.; Simon, M.; Rafailovich, M.H.; Rigas, B. Platinum folate nanoparticles toxicity: Cancer vs. normal cells. Toxicol. Vitr. 2013, 27, 882-889. [CrossRef]

225. Yamagishi, Y.; Watari, A.; Hayata, Y.; Li, X.; Kondoh, M.; Tsutsumi, Y.; Yagi, K. Hepatotoxicity of sub-nanosized platinum particles in mice. Pharmazie 2013, 68, 178-182.

226. Ho, Y.P.; Au-Yeung, S.C.; To, K.K. Platinum-based anticancer agents: Innovative design strategies and biological perspectives. Med. Res. Rev. 2003, 23, 633-655. [CrossRef]

227. Hamelers, I.H.; Staffhorst, R.W.; Voortman, J.; de Kruijff, B.; Reedijk, J.; en Henegouwen, P.M.V.B.; de Kroon, A.I. High Cytotoxicity of Cisplatin Nanocapsules in Ovarian Carcinoma Cells Depends on Uptake by Caveolae-Mediated Endocytosis. Clin. Cancer Res. 2009, 15, 2009. [CrossRef]

228. Liu, L.; Miao, P.; Xu, Y.; Tian, Z.; Zou, Z.; Li, G. Study of $\mathrm{Pt} / \mathrm{TiO}_{2}$ nanocomposite for cancer-cell treatment. J. Photochem. Photobiol. B Biol. 2010, 98, 207-210. [CrossRef] [PubMed]

229. Guo, F.; Yu, M.; Wang, J.; Tan, F.; Li, N. The mitochondria-targeted and IR780-regulated theranosomes for imaging and enhanced photodynamic/photothermal therapy. RSC Adv. 2016, 6, 11070-11076. [CrossRef]

230. Phan, T.T.V.; Bui, N.Q.; Moorthy, M.S.; Lee, K.D.; Oh, J. Synthesis and In Vitro Performance of Polypyrrole-Coated Iron-Platinum Nanoparticles for Photothermal Therapy and Photoacoustic Imaging. Nano. Res. Lett. 2017, 12, 570. [CrossRef] [PubMed]

231. Sun, Y.; Miao, H.; Ma, S.; Zhang, L.; You, C.; Tang, F.; Yang, C.; Tian, X.; Wang, F.; Luo, Y.; et al. FePt-Cys nanoparticles induce ROS-dependent cell toxicity, and enhance chemo-radiation sensitivity of NSCLC cells in vivo and in vitro. Cancer Lett. 2018, 418, 27-40. [CrossRef] [PubMed]

232. Ankkeev, V.; Maohong, F.I. Supercritical Fluid Technology for Energy and Environmental Applications, 1st ed.; Elsevier: Amsterdam, The Netherlands, 2014.

233. Wang, X.; Guo, Z. Targeting and delivery of platinum based anticancer drugs. Chem. Soc. Rev. 2013, 42, 202-224. [CrossRef] [PubMed]

234. Maeda, H.; Matsumura, Y. Tumoritropic and lymphotropic principles of macromolecular drugs. Crit Rev. Drug Carr. Syst. 1989, 6, 193-210.

235. Matsumura, Y.; Maeda, H.A. New concept for macromolecular therapeutics in cancer chemotherapy: Mechanism of tumoritropic accumulation of proteins and the antitumor agent smancs. Cancer Res. 1986, 46, 6387-6392.

236. Bazak, R.; Houri, M.; El Achy, S.; Hussein, W.; Refaat, T. Passive targeting of nanoparticles to cancer: A comprehensive review of the literature. Mol. Clin. Oncol. 2014, 2, 904-908. [CrossRef]

237. Hobbs, S.K.; Monsky, W.L.; Yuan, F.; Roberts, W.G.; Griffith, L.; Torchilin, V.P.; Jain, R.K. Regulation of transport pathways in tumor vessels: Role of tumor type and microenvironment. Proc. Natl. Acad. Sci. USA 1998, 95, 4607-4612. [CrossRef] 
238. Bertrand, N.; Wu, J.; Xu, X.; Kamaly, N.; Farokhzad, O.C. Cancer nanotechnology: The impact of passive and active targeting in the era of modern cancer biology. Adv. Drug Deliv. Rev. 2014, 66, 2-25. [CrossRef]

239. Padera, T.P.; Stoll, B.R.; Tooredman, J.B.; Capen, D.; di Tomaso, E.; Jain, R.K. Pathology: Cancer cells compress intratumour vessels. Nature 2004, 427, 695. [CrossRef] [PubMed]

240. Cabral, H.; Nishiyama, N.; Kataoka, K. Optimization of (1,2-diamino-cyclohexane) platinum (II)-loaded polymeric micelles directed to improved tumor targeting and enhanced antitumor activity. J. Control. Release 2007, 121, 146-155. [CrossRef] [PubMed]

241. Alexis, F.; Pridgen, E.; Molnar, L.K.; Farokhzad, O.C. Factors affecting the clearance and biodistribution of polymeric nanoparticles. Mol. Pharm. 2008, 5, 505-515. [CrossRef]

242. Boulikas, T.; Stathopoulos, G.P.; Volakakis, N.; Vougiouka, M. Systemic Lipoplatin infusion results in preferential tumor uptake in human studies. Anticancer Res. 2005, 25, 3031-3039.

243. Steinhauser, I.; Spankuch, B.; Strebhardt, K.; Langer, K. Trastuzumab-modified nanoparticles: Optimisation of preparation and uptake in cancer cells. Biomaterials 2006, 27, 4975-4983. [CrossRef]

244. Desgrosellier, J.S.; Cheresh, D.A. Integrins in cancer: Biological implications and therapeutic opportunities. Nat. Rev. Cancer 2010, 10, 9-22. [CrossRef]

245. Kamaly, N.; Xiao, Z.; Valencia, P.M.; Radovic-Moreno, A.F.; Farokhzad, O.C. Targeted polymeric therapeutic nanoparticles: Design, development and clinical translation. Chem. Soc. Rev. 2012, 41, 2971-3010. [CrossRef]

246. Matherly, L.H.; Goldman, D.I. Membrane transport of folates. Vitam. Horm. 2003, 66, 403-456.

247. Byrne, J.D.; Betancourt, T.; Brannon-Peppas, L. Active targeting schemes for nanoparticle systems in cancer therapeutics. Adv. Drug Deliv. Rev. 2008, 60, 1615-1626. [CrossRef]

248. Yu, B.; Tai, H.C.; Xue, W.; Lee, L.J.; Lee, R.J. Receptor-targeted nano-carriers for therapeutic delivery to cancer. Mol. Membr. Biol. 2010, 27, 286-298. [CrossRef]

249. Sudimack, J.; Lee, R.J. Targeted drug delivery via the folate receptor. Adv. Drug Deliv. Rev. 2000, 41, 147-162. [CrossRef]

250. Low, P.S.; Kularatne, S.A. Folate-targeted therapeutic and imaging agents for cancer. Curr. Opin. Chem. Biol. 2009, 13, 256-262. [CrossRef] [PubMed]

251. Dhar, S.; Liu, Z.; Thomale, J.; Dai, H.; Lippard, S.J. Targeted single-wall carbon nanotube-mediated Pt (IV) prodrug delivery using folate as a homing device. J. Am. Chem. Soc. 2008, 130, 11467-11476. [CrossRef] [PubMed]

252. Zhang, Y.; Hong, H.; Cai, W. Tumor-targeted drug delivery with aptamers. Curr. Med. Chem. 2011, 18, 4185-4194. [CrossRef] [PubMed]

253. Dhar, S.; Gu, F.X.; Langer, R.; Farokhzad, O.C.; Lippard, S.J. Targeted delivery of cisplatin to prostate cancer cells by aptamer functionalized Pt (IV) prodrug-PLGA-PEG nanoparticles. Proc. Natl. Acad. Sci. USA 2008, 105, 17356-17361. [CrossRef]

254. Dhar, S.; Kolishetti, N.; Lippard, S.J.; Farokhzad, O.C. Targeted delivery of a cisplatin prodrug for safer and more effective prostate cancer therapy in vivo. Proc. Natl. Acad. Sci. USA 2011, 108, 1850-1855. [CrossRef]

255. Leo, A.J.; Oluwafemi, O.S. Plant-mediated synthesis of platinum nanoparticles using water hyacinth as an efficient biomatrix source-An eco-friendly development. Mater. Lett. 2017, 196, 141-144.

256. Karthik, R.; Sasikumar, R.; Chen, S.M.; Govindasamy, M.; Kumar, J.V.; Muthuraj, V. Green synthesis of Platinum Nanoparticles Using Quercus Glauca Extract and its electrochemical oxidation of Hydrazine in water samples. Int. J. Electrochem. Sci. 2016, 11, 8245-8255. [CrossRef]

257. Nellore, J.; Pauline, C.; Amarnath, K. Bacopa monnieri Phytochemicals Mediated Synthesis of Platinum Nanoparticles and Its Neurorescue Effect on 1-Methyl 4-Phenyl 1,2,3,6 Tetrahydropyridine-Induced Experimental Parkinsonism in Zebrafish. J. Neurodegener. Dis. 2013. [CrossRef]

258. Vinod, V.T.P.; Saravanan, P.; Sreedhar, B.; Devi, D.K.; Sashidhar, R. A facile synthesis and characterization of $\mathrm{Ag}$, $\mathrm{Au}$ and Pt nanoparticles using a natural hydrocolloid gum kondagogu (Cochlospermum gossypium). Colloids Surf. B Biointerfaces 2011, 83, 291-298. [CrossRef]

259. Lengke, M.F.; Fleet, M.E.; Southam, G. Synthesis of platinum nanoparticles by reaction of filamentous cyanobacteria with platinum (IV) chloride complex. Langmuir 2006, 22, 7318-7323. [CrossRef] [PubMed]

260. Brayner, R.; Barberousse, H.; Hemadi, M.; Djedjat, C.; Yéprémian, C.; Coradin, T.; Livage, J.; Fiévet, F.; Couté, A. Cyanobacteria as bioreactors for the synthesis of $\mathrm{Au}, \mathrm{Ag}, \mathrm{Pd}$, and $\mathrm{Pt}$ nanoparticles via an enzyme-mediated route. J. Nanosci. Nanotechnol. 2007, 7, 2696-2708. [CrossRef] [PubMed] 
261. Manikandan, V.; Velmurugan, P.; Park, J.H.; Lovanh, N.; Seo, S.K.; Jayanthi, P.; Park, Y.J.; Cho, M.; Oh, B.T. Synthesis and antimicrobial activity of palladium nanoparticles from Prunus x yedoensis leaf extract. Mater. Lett. 2016, 185, 335-338. [CrossRef]

262. Rokade, S.S.; Komal, A.J.; Mahajan, K.; Patil, S.; Tomar, G.; Dubal, D.S.; V Parihar, V.S.; Kitture, R.; Bellare, J.R.; Ghosh, S. Gloriosa superba Mediated Synthesis of Platinum and Palladium Nanoparticles for Induction of Apoptosis in Breast Cancer. Bioinorg. Chem. Appl. 2018, 2018. [CrossRef]

263. Kumar, K.M.; Mandal, B.K.; Tammina, S.K. Green synthesis of nano platinum using naturally occurring polyphenols. RSC Adv. 2013, 3, 4033-4039. [CrossRef]

264. Zheng, B.; Kong, T.; Jing, X.; Odoom-Wubah, T.; Li, X.; Sun, D.; Lu, F.; Zheng, Y.; Huang, J.; Li, Q. Plant-mediated synthesis of platinum nanoparticles and its bioreductive mechanism. J. Colloid Interface Sci. 2013, 396, 138-145. [CrossRef]

(C) 2019 by the authors. Licensee MDPI, Basel, Switzerland. This article is an open access article distributed under the terms and conditions of the Creative Commons Attribution (CC BY) license (http://creativecommons.org/licenses/by/4.0/). 